\title{
Information System Capabilities and Organizational Performance: Comparing Three Models
}

\author{
Yen-Ching OuYang \\ Department of Commerce Automation \& Management \\ College of Management \\ National Pingtung University, Taiwan \\ ouyang@mail.nptu.edu.tw
}

\begin{abstract}
How information system capabilities affect firm performance is an important issue. However, different research approaches often result in inconsistent results. This study compares three conceptual (knowledge-based view, resource-based view, and contingency-based view) and two modeling approaches (antecedents versus moderators) that can be used to assess the strategic value of information systems. The goal is to examine different ways to model various organizational factors. We also provide three different views to buttress arguments about the need for different types of moderator analyses. The advantage of such an approach is that managers and researchers can better differentiate potential influential factors into antecedents and moderators, and understand their different roles in KM implementation. This study uses data collected from 274 organizations to compare different prevailing views in KM research. The result indicates that the contingency approach can provide more insight into the role of different contextual variables. Some variables, such as the business process complexity and market orientation, found insignificant in the contingency-based model are found to be significant antecedents for improving managerial performance. Some variables that are found insignificant in the resource-based model are found to be significant moderators. For example, business process complexity and information technology (IT) support are not significant, as enablers proved to moderate the relationship between KMC and financial performance as homologizer and suppressor, respectively. The relationship between KM capabilities and financial performance is also moderated by leadership style and IT readiness of an organization. The results of this analysis show that the contingency model, with moderating effect, is more comprehensive and meaningful for future research.
\end{abstract}

Keywords: Information systems capability, Knowledge management, Performance, Knowledge-based view, Resource-based view, Contingency-based view

Citation: OuYang, Y. C. (2017). "Information System Capabilities and Organizational Performance: Comparing Three Models," Pacific Asia Journal of the Association for Information Systems, 9(1), pp. 1-28. 


\section{Introduction}

A large volume of research has investigated how information system capabilities affect firm performance. Although most results are positive but the effects of specific factors are often inconsistent. In this research, we intend to compare how different ways of modeling them could lead to different results by comparing three different theoretical models and two different ways of positioning organizational factors (as antecedents or moderators). The information systems we use are knowledge management systems that have been adopted in many organizations.

The growing importance of knowledge has motivated executives to focus on better managing their knowledge assets. Knowledge-management capabilities (KMC) that support the codification, conversion, sharing, and application of this critical asset have received an increasing amount of attention in both research and practical settings. Many companies have allocated resources to create $\mathrm{KM}$ practices with the expectation that they should improve organizational performance.

Much research has been done on the performance implications of $\mathrm{KM}$ practices, but with divergent results. Most explanations provided to account for the inconsistent results have focused on issues associated with KM capability definition (Gold et al., 2001; Becerra-Fernandez and Sabherwal, 2001; Lee and Choi, 2003; Eftekharzadeh, 2008), moderator (Lee et al., 2001; Kankanhalli et al., 2005; Lee and Sukoco, 2007; Liu and Tsai, 2007), and choice of dependent variables (managerial performance or financial performance). However, the use of divergent theoretical frameworks as a source of inconsistency has received relatively little attention.

Indeed, the role of knowledge-management capability shown in prior research is not consistent. Three perspectives have been predominantly used as the conceptual base to study the strategic value in KM research: knowledge-based view (KBV), resourcebased view (RBV), and contingency-based view (CBV). Studies grounded in the KBV consider that knowledge is a kind of strategic resource and an antecedent that can directly influence performance (Becerra-Fernandez and Sabherwal, 2001; Choi and Lee, 2003; Patnayakuni et al., 2006; Eftekharzadeh, 2008). Studies grounded in the RBV typically consider that the research model has strategic resources that serve as antecedents that can directly influence $\mathrm{KM}$ capability and performance (Tanriverdi, 2005).

In comparison, the contingency-based view is much less studied. While some studies recognize both knowledge enablers and capabilities as antecedents of organizational performance, few recognize knowledge enablers as contingency factors of $\mathrm{KM}$ capabilities. While the limited studies investigate the moderating relationships among antecedents, KM capabilities, or organizational performance (Kankanhalli et al., 2005; Liu and Tsai, 2007), they fail to explore the differences of model design between antecedents and moderators distinction. If researchers and practitioners understand these relationships in a designed model, they can stand a better recognition of improving performance.

Therefore, the purpose of our research is to evaluate these three theoretical models, focusing in particular on the contingencybased view in an attempt to help improve its application to research on the strategic value of contingency factors in a knowledge -management research context specifically and possibly other types of information systems in general. The contingency view examines how some salient factors moderate the KMC-organizational performance relationship. Factors that moderate such a relationship interact with KM capabilities in such a way that the effect of KM capabilities differs at various levels of the moderators. For instance, if the effect of $\mathrm{KMC}$ on performance is greater for firms that have a low level of production complexity, production complexity would be 
said to moderate the relationship. We therefore formulate a model that treats selected variables as potential moderators and conduct a sophisticated moderating analysis that tells us which actually are moderators and which are predictors. The method can alleviate the potential errors in moderator analysis outlined in the studies by Carte and Russell (2003), and Sharma et al. (1981).

More specifically, the specific research questions addressed are:

(1) Does the KM capability impact on organizational performance? (i.e., basic model--KBV)

(2) Do the KM capability and resources impact on organizational performance? (i.e., extend model--RBV)

(3) How do resources impact the relationship between KM capability and organizational performance? (i.e., moderated model--CBV)

(4) How do these three theoretical views (i.e., KBV, RBV, and CBV) differ in terms of their ability to explain the strategic value of information system capability?

This study has dual objectives: (1) to offer three complementary theoretical models and issues related to the relationships among information system capability, other organizational factors and firm performance, and (2) to demonstrate how different effects may be found when factors are modeled differently.

The remainder of the paper is organized as follows. The next section presents theoretical background of three different views and their relative advantages. This is followed by a description of the research model and hypotheses. The next section describes our research methodology, which includes a description of the extended mechanism for moderator analysis. Empirical findings are shown in the following section. Conclusion and discussion of findings are in the last section.

\section{Theoretical Background and Hypotheses}

Previous empirical studies have investigated the relationships among knowledge management factors. They can be classified into three categories depending on how they identify the relationships, as follows:

The first category deals with the relationship between knowledge capability and performance. The knowledge-based view (KBV) is shown in Figure 1a. It relates KMC directly to organizational performance, providing the basis for most of the research concerning KM capabilities as determinants of organizational performance. It was originally proposed by Bierly and Chakrabarti (1996), and has been employed by Becerra-Fernandez and Sabherwal (2001), and many other researchers. The model conceives of $\mathrm{KMC}$ as a valuable enabler of an organization for enhancing its performance.

The second category deals with relationships among knowledge enablers, knowledge capabilities, and organizational performance. An extension of the basic model, called the "extended model," has also been popular. Figure $1 \mathrm{~b}$ illustrates the model that treats antecedent factors as enablers for explaining the impact of $\mathrm{KM}$ capabilities on performance. As the Barney's (1991) resource-based view (RBV), resources confer a competitive advantage to a firm only when they are firm-specific, valuable, rare, inimitable, and nonsubstitutable. The RBV argues that firms possess resources, a subset of which enables them to achieve competitive advantage, and a further subset of which leads to superior long-term performance.

A major shortcoming of the enabler approach based on RBV is that it assumes that the same contingent factors (treated as enablers) influence KMC and performance in the same way in all organizations. Therefore, the final category deals with relationships among contingent factors, 
knowledge enablers, capabilities, and organizational performance (shown as Figure 1c). In the contingency-based view, contextual variables are treated as moderators in analyzing their roles in affecting the effect of KMC on organizational performance (Kankanhalli et al., 2005). The impact of KM capabilities of an organization on its performance is contingent upon salient industrial and management factors.

This comparison is highlighted in Figure 1. Contingency Theory states that the effects of the organization's employment of its capabilities are contingent on various situational factors. It posits that the alignment between the "patterns of relevant contextual, structural, and strategic factors" (Doty et al., 1993, p.1196) leads to superior firm performance, and that misalignment results in performance erosion (Oh and Pinsonneault, 2007). A broad view of contingency theory is that the structure of an organization depends on salient industrial and management factors. The literature outlined in Table 1 and Figure 1 indicates that some studies have pointed out that KM capability alignment is positively associated with performance measures, such as perceived firm performance (Gold et al., 2001; Choi and Lee, 2003; Fedor et al., 2003; Liu et al., 2004; Cui et al., 2005) and financial performance (Bierly and Chakrabarti, 1996; Tanriverdi, 2005).

However, the relationship between contingency factors, KM capabilities, and performance appears to be underinvestigated, and findings have generally been inconclusive. As can be readily seen, only a few studies have examined moderators, and most studies have been RBV-based. A further examination of the studies also indicates that the examination of the moderating effects is not very rigorous. In particular, these studies did not differentiate the types of moderators, as presented in Sharma et al. (1981), and may incur common errors noted in Carte and Russell (2003).

In short, the literature on knowledge management has generally relied on one of three theoretical perspectives to relate knowledge management capabilities to organizational performance: knowledgebased view (i.e., KMC-performance perspective) (Choi and Lee, 2003), the resource-based view (i.e., enablers-KMCperformance perspective) (McEvily and Chakravarthy, 2002), and, to a less extent, the contingency-based perspective (Birkinshaw et al., 2002).
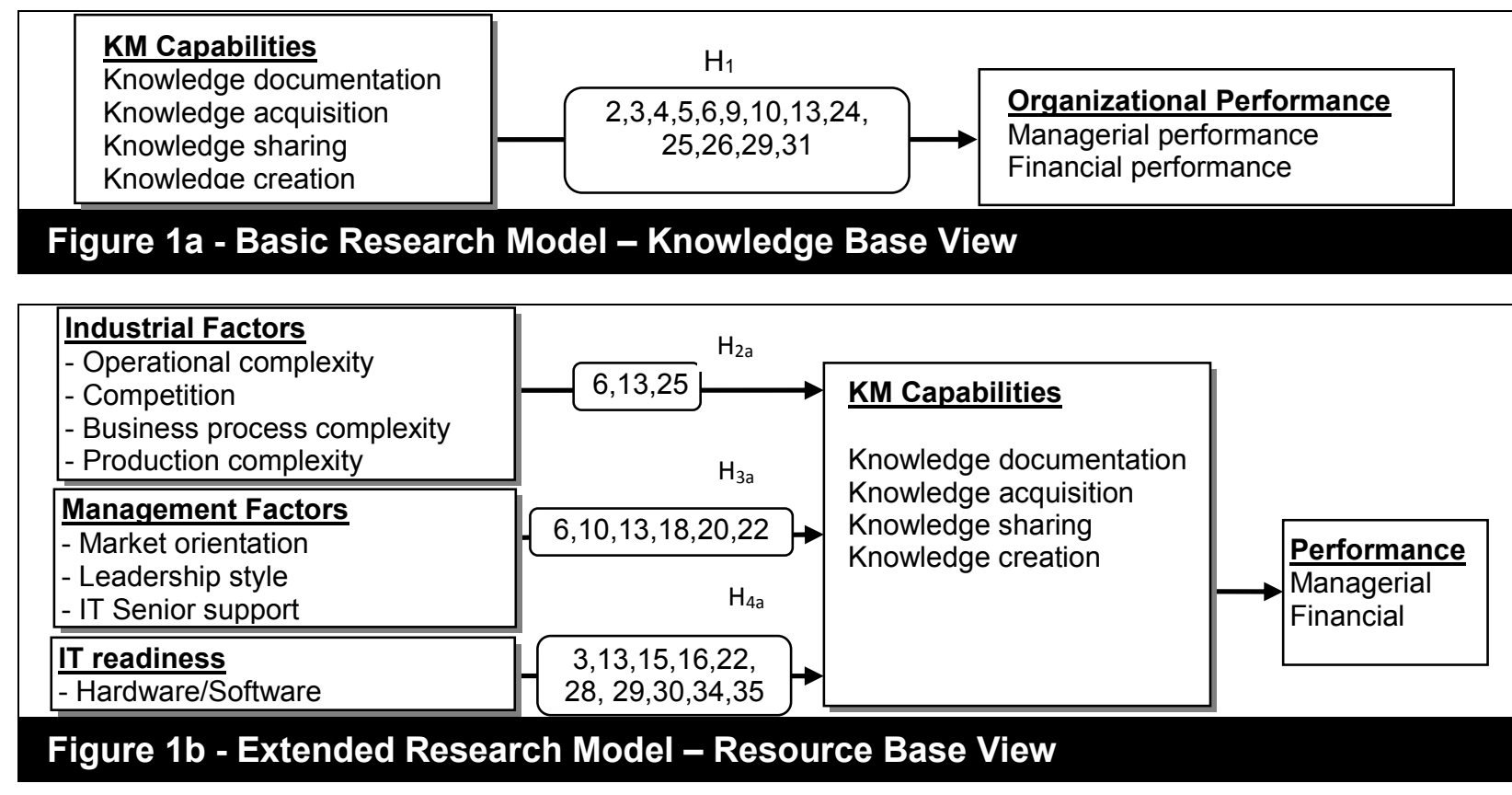

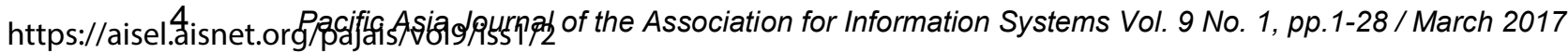




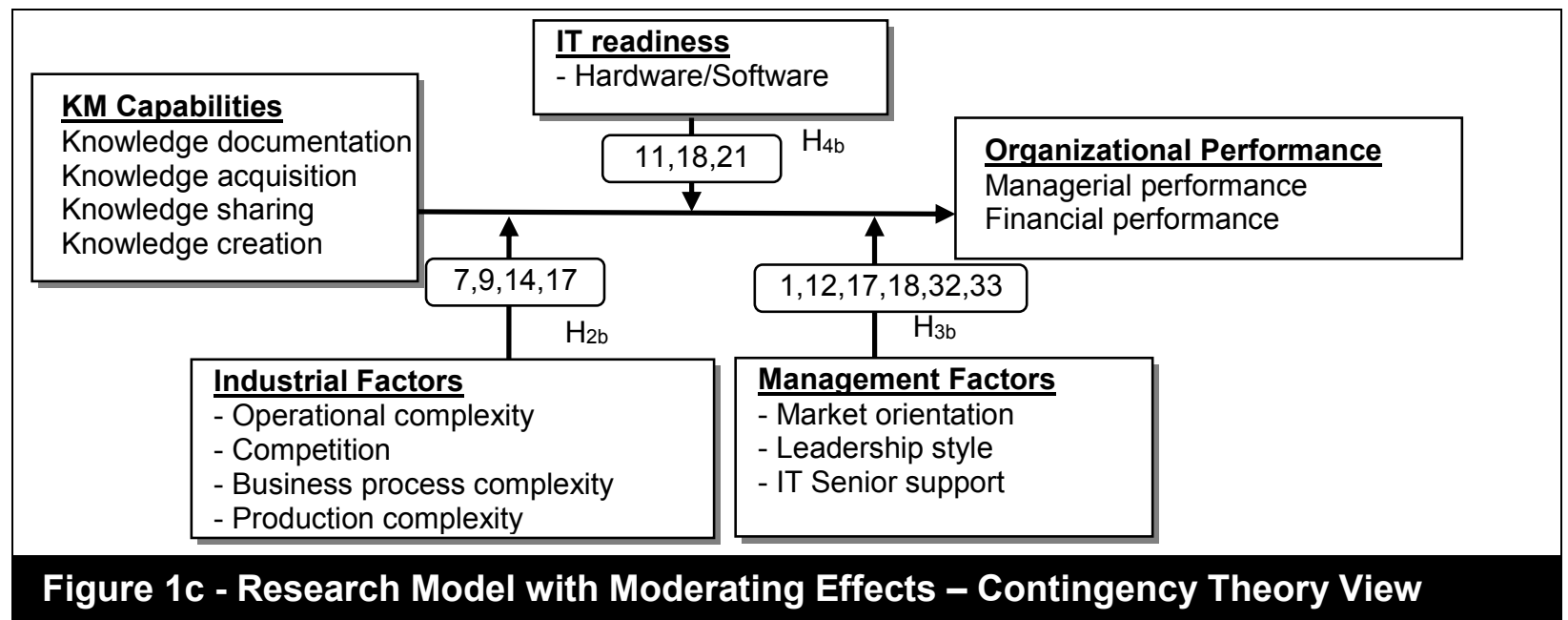

Notes: (1)Attharangsun \& Ussahawanitchakit,2008 (2)Becerra-Fernandez \& Sabherwal,2001 (3)Bierly \& Chakrabarti,1996 (4)Choi \& Lee,2003 (5)Chuang,2004 (6)Cui et al.,2005 (7)Dyer \& Nobeoka,2000 (8)Eftekharzadeh,2008 (9)Eisenhardt \& Tabrizi,1995 (10)Fedor et al.,2003 (11)Gandhi,2004 (12)Gatingnon \& Xuereb,1997 (13)Gold et al.,2001 (14)Grewal \& Tansuhaj,2001 (15)Hislop,2002 (16)Jackson,1999 (17)Jaworski \& Kohli,1993 (18)Juntarung \& Ussahawanitchakit,2008 (19)Kluge et al.,2001 (20)Kulkarni et al.,2006/2007 (21)Lakshman \& Parente,2008 (22)Lee \& Choi,2003 (24)Lee \& Sukoco,2007 (25)Liu \& Tsai, 2007 (26)Liu et al.,2004 (27)Liu et al.,2005 (28)Marwick,2001 (29) Tanriverdi,2005 (30)Wang et al.,2007 (31)Yang,2005 (32) Fang et al., 2010 (33) Joshi et al., 2010 (34) Choi et al., 2010 (35) Kuo and Ye, 2010

\section{Knowledge Management Capability}

Knowledge-management capability is the organizational capability to document, acquire, share, and create Knowledge/information to address rapidly changing environments. Knowledge documentation capability focuses on how structured knowledge can be captured, codified, and stored. Document capability must be done in a form/structure that will eventually build the knowledge base (Durcikova and Gray, 2009). Knowledgeacquisition capability is the nontrivial extraction of implicit, previously unknown, and potentially useful information from data. Knowledge acquisition will strongly affect business performance. Firms with stronger acquisition capability will get more sources of knowledge and enhance performance (Lee and Choi, 2010).
Knowledge-sharing capability occurs at various levels: transfer of Knowledge between individuals, from individuals to explicit sources, from individuals to groups, between groups, across groups, and from the group to the organization (Alavi and Leidner, 2001). As literature shows, knowledge-transfer capability can bring many advantages to organizations (i.e., Table 1 literature), and nowadays knowledge-transfer capability is part of organizational life (Liu et al., 2010; Pee et al., 2010). Knowledge-creation capability involves the development of new content or replacing existing content within tacit and explicit knowledge of an organization. Nonaka and Takeuchi (1995) propose that knowledge could be created through the interaction of explicit knowledge and tacit knowledge. 


\section{Table 1 - Selected Empirical Studies on the Effects of KM Antecedent-Capability Alignment on Firm Performances}

\begin{tabular}{|c|c|c|c|c|c|c|}
\hline \multirow[b]{2}{*}{ No } & \multirow[b]{2}{*}{ Study } & \multirow[b]{2}{*}{ Model } & \multirow{2}{*}{$\begin{array}{l}\text { Antecedent factors(AF); } \\
\text { KM capability (KMC); } \\
\text { Moderators(M) }\end{array}$} & \multicolumn{2}{|c|}{$\begin{array}{c}\begin{array}{c}\text { Organizational performance } \\
\text { measures }\end{array} \\
\end{array}$} & \multirow[b]{2}{*}{ Results } \\
\hline & & & & $\begin{array}{l}\text { Managerial } \\
\text { performance }\end{array}$ & $\begin{array}{c}\text { Financial } \\
\text { performance }\end{array}$ & \\
\hline 1. & $\begin{array}{l}\text { Gold, et al. } \\
(2001)\end{array}$ & Extended & $\begin{array}{l}\text { AF :Technology, structure, } \\
\text { culture, } \\
\text { KMC:(Acquisition \& Conversion \& } \\
\text { Application \& Protection) }\end{array}$ & $\begin{array}{l}\text { Organizational } \\
\text { effectiveness: ability to } \\
\text { innovate new products; } \\
\text { market response times; } \\
\text { internal processes }\end{array}$ & - & $\begin{array}{l}\text { The paths between infrastructure and process } \\
\text { capabilities and the performance variable are positive } \\
\text { and of high magnitude. }\end{array}$ \\
\hline 2. & $\begin{array}{l}\text { Lee, et al. } \\
(2001)\end{array}$ & Moderated & $\begin{array}{l}\text { KMC: Level of knowledge } \\
\text { acquisition form customers; } \\
\text { Participation of Employees in } \\
\text { knowledge Dissemination } \\
\text { M: Process management; } \\
\text { Innovation-marketing fit }\end{array}$ & Product quality & & $\begin{array}{l}\text { The level of knowledge acquisition form customers } \\
\text { and the participation of employees in knowledge } \\
\text { dissemination have an impact on product quality. } \\
\text { Moderator have significant effect on product quality }\end{array}$ \\
\hline 3. & $\begin{array}{l}\text { Becerra- } \\
\text { Fernandez \& } \\
\text { Sabherwal } \\
(2001)\end{array}$ & Basic & $\begin{array}{lr}\text { KMC: } & \text { (Externalization, } \\
\text { Combination, } & \text { Socialization, } \\
\text { Internationalization) } & \end{array}$ & $\begin{array}{l}\text { KM satisfaction with } \\
\text { availability, sharing, } \\
\text { management }\end{array}$ & & $\begin{array}{l}\text { Overall combination and externalization, but not } \\
\text { internalization and socialization, affect knowledge } \\
\text { satisfaction }\end{array}$ \\
\hline 4. & $\begin{array}{l}\text { Choi \& Lee } \\
\text { (2003) }\end{array}$ & Basic & $\begin{array}{l}\text { KMC: (Codification/ Storage \& } \\
\text { Acquisition/ Sharing) } \\
\text { Four KM styles: Dynamic, system- } \\
\text {, human-oriented, and passive }\end{array}$ & \begin{tabular}{|l|} 
overall success, \\
market share, growth \\
rate, profitability, \\
innovativeness, and \\
business size \\
compared with key \\
competitors
\end{tabular} & - & $\begin{array}{l}\text { Dynamic style results in higher performance, Human- } \\
\text { and system-oriented styles do not show any } \\
\text { difference in terms of performance, the passive style } \\
\text { is less effective. }\end{array}$ \\
\hline 5. & $\begin{array}{l}\text { Lee \& Choi } \\
(2003)\end{array}$ & Extended & $\begin{array}{l}\text { AF: Culture, Structure, People, } \\
\text { Information Technology, } \\
\text { KMC: knowledge creation, } \\
\text { Processes-socialization, } \\
\text { Externalization, Combination, } \\
\text { Internalization }\end{array}$ & $\begin{array}{l}\text { Organizational } \\
\text { creativity: novel ideas, } \\
\text { organizational } \\
\text { performance: } \\
\text { compared with key } \\
\text { competitors profitable, } \\
\text { innovative, market } \\
\text { share }\end{array}$ & & $\begin{array}{l}\text { Collaboration, trust, learning and centralization found } \\
\text { to be "relatively significant predictors for knowledge } \\
\text { creation". Knowledge creation positively related with } \\
\text { organizational creativity, which is positively related } \\
\text { with organizational performance. }\end{array}$ \\
\hline 6. & $\begin{array}{l}\text { Liu, et al. } \\
(2004)\end{array}$ & Basic & 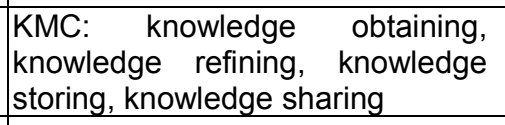 & $\begin{array}{l}\text { Competitiveness: } \\
\text { enterprise forecasting } \\
\text { ability, sales ability }\end{array}$ & $\begin{array}{l}\text { financial } \\
\text { capability }\end{array}$ & $\begin{array}{l}\text { Knowledge management capability had an effect on } \\
\text { competitiveness }\end{array}$ \\
\hline 7. & $\begin{array}{l}\text { Chuang } \\
(2004)\end{array}$ & Basic & $\begin{array}{l}\text { Structural, Cultural, Human and } \\
\text { Technical KM }\end{array}$ & \begin{tabular}{|l|} 
Competitive \\
advantage, \\
innovativeness, market \\
position, mass \\
customization
\end{tabular} & & $\begin{array}{l}\text { Technical KM resource had no association with } \\
\text { competitive advantage. Other } 3 \text { structural, cultural and } \\
\text { human KM resources found "to be essential for } \\
\text { competitive advantage" }\end{array}$ \\
\hline
\end{tabular}




\begin{tabular}{|c|c|c|c|c|c|c|}
\hline 8. & $\begin{array}{l}\text { Cui, } \\
\text { al.(2005) }\end{array}$ & Extended & $\begin{array}{l}\text { AF: competitive intensity, Market } \\
\text { dynamism } \\
\text { KMC: acquisition, conversion, } \\
\text { application }\end{array}$ & $\begin{array}{l}\text { Subsidiary } \\
\text { performance }\end{array}$ & & $\begin{array}{l}\text { Competitive intensity and market dynamism } \\
\text { individually influence KMC; } \\
\text { A significant, positive relationship between a KMC and } \\
\text { its performance. }\end{array}$ \\
\hline 9. & $\begin{array}{l}\text { Tanriverdi } \\
(2005)\end{array}$ & Extended & $\begin{array}{l}\text { AF: IT relatedness } \\
\text { KMC: (Creation \& Transfer \& } \\
\text { Integrate \& Leverage) }\end{array}$ & - & $\begin{array}{l}\text { (Tobin's q, } \\
\text { ROA) }\end{array}$ & $\begin{array}{l}\text { IT relatedness of the firm's business units enhances } \\
\text { cross-unit KMC; KMC leads to superior firm } \\
\text { performance }\end{array}$ \\
\hline 10. & $\begin{array}{l}\text { Kankanhalli, } \\
\text { Tan, and Wei } \\
\text { (2005) }\end{array}$ & $\begin{array}{l} \\
\text { Extended } \\
+ \\
\text { Moderated } \\
\end{array}$ & $\begin{array}{l}\text { AF: Costs (Loss of knowledge } \\
\text { power, Codification effort); } \\
\text { Extrinsic Benefits (Organizational } \\
\text { reward, Image); Intrinsic Benefits } \\
\text { (Knowledge self-efficacy, } \\
\text { Enjoyment in helping others) } \\
\text { M: Contextual factors } \\
\text { (generalized trust, pro-sharing } \\
\text { norms, and identification) }\end{array}$ & $\begin{array}{l}\text { Usage of Electronic } \\
\text { knowledge } \\
\text { repositories (EKR) } \\
\text { system }\end{array}$ & & $\begin{array}{l}\text { Knowledge self-efficacy and enjoyment in helping } \\
\text { others significantly impact EKR usage by knowledge } \\
\text { contributors. Extrinsic benefits impact EKR usage } \\
\text { contingent on particular contextual factors whereas } \\
\text { the effects of intrinsic benefits on EKR usage are not } \\
\text { moderated by contextual factors. The loss of } \\
\text { knowledge power and image do not appear to impact } \\
\text { EKR usage by knowledge contributors. Moderators } \\
\text { moderate the impact of codification effort, reciprocity, } \\
\text { and organizational reward on EKR usage, } \\
\text { respectively. }\end{array}$ \\
\hline 11. & $\begin{array}{l}\text { Patnayakuni, } \\
\text { et al. (2006) }\end{array}$ & Basic & KMC: Integration & $\begin{array}{l}\text { Process/Outcome } \\
\text { Performance }\end{array}$ & & $\begin{array}{l}\text { Explicit knowledge integration affect performance } \\
\text { significantly }\end{array}$ \\
\hline 12. & $\begin{array}{l}\text { Lee and } \\
\text { Sukoco } \\
(2007)\end{array}$ & $\begin{array}{l}\text { Extended } \\
+ \\
\\
\text { Moderated }\end{array}$ & $\begin{array}{l}\text { AF: Entrepreneurial Orientation } \\
\text { KMC: (Acquisition, Conversion, } \\
\text { Application, Protection) } \\
\text { M: Social capital }\end{array}$ & $\begin{array}{l}\text { Innovation, } \\
\text { Competence } \\
\text { upgrading, } \\
\text { Organizational } \\
\text { effectiveness }\end{array}$ & & $\begin{array}{l}\text { Entrepreneurial orientation has a positive influence on } \\
\text { the capability of organization to manage their } \\
\text { knowledge, on new product or process innovation, on } \\
\text { the upgrading of their competence as well as on } \\
\text { organizational effectiveness. Social capital moderates } \\
\text { the effect on entrepreneurial orientation and KMC on } \\
\text { the dependent variables }\end{array}$ \\
\hline 13. & \begin{tabular}{|l|} 
Liu and Tsai \\
$(2007)$
\end{tabular} & \begin{tabular}{|l|} 
Extended + \\
Moderated \\
\end{tabular} & $\begin{array}{l}\text { AF: Financial, Customer, Internal } \\
\text { business process, Learning and } \\
\text { growth } \\
\text { KMC: Acquisition, Creation, } \\
\text { Storing, Sharing } \\
\text { M: Enterprise characteristics, } \\
\text { Enterprise scale }\end{array}$ & $\begin{array}{l}\text { Business } \\
\text { performance, } \\
\text { Organization long-term } \\
\text { advantage resource, }\end{array}$ & \begin{tabular}{|l|} 
Financial \\
performance
\end{tabular} & $\begin{array}{l}5 \% \text { to } 10 \% \text { improvement in performance in the } \\
\text { customer, financial, and internal business process } \\
\text { areas and a } 10 \% \text { to } 15 \% \text { improvement in } \\
\text { performance in the learning and growth area, }\end{array}$ \\
\hline 14. & \begin{tabular}{|l|} 
Eftekharzadeh \\
(2008)
\end{tabular} & Basic & $\begin{array}{l}\text { KMC: (Sharing \& distribution, } \\
\text { Generation \& development, } \\
\text { Codification \& Storing) }\end{array}$ & $\begin{array}{l}\text { KM performance } \\
\text { (production and } \\
\text { organizational } \\
\text { performance) }\end{array}$ & & $\begin{array}{l}\text { There is a positive relationship between } \mathrm{KMC} \text { and } \mathrm{KM} \\
\text { performance }\end{array}$ \\
\hline 15. & $\begin{array}{l}\text { Kuo and Ye } \\
(2010)\end{array}$ & Extended & $\begin{array}{l}\text { AF: Perception of IT } \\
\text { KMC: Knowledge Management }\end{array}$ & $\begin{array}{l}\text { Organizational } \\
\text { performance }\end{array}$ & & $\begin{array}{l}\mathrm{IT}, \mathrm{KM} \text { and organizational performance are strongly } \\
\text { correlated to each other }\end{array}$ \\
\hline 16. & $\begin{array}{l}\text { Fang, et } \\
(2010)\end{array}$ & Moderated & $\begin{array}{l}\text { KMC: level of knowledge sharing } \\
\text { from parent firms to subsidiaries } \\
\text { M: use of expatriates }\end{array}$ & & \begin{tabular}{|l|} 
Financial \\
performance \\
(profitability)
\end{tabular} & $\begin{array}{l}\text { KMC positively affects financial performance. Sharing } \\
\text { of different types of knowledge has varying effects on } \\
\text { financial performance contingent on the characteristics } \\
\text { of senior management in the subsidiary. }\end{array}$ \\
\hline
\end{tabular}


Pacific Asia Journal of the Association for Information Systems, Vol. 9, Iss. 1 [2017], Art. 2

Information System Capabilities and Organizational Performance / OuYang

\begin{tabular}{|c|c|c|c|c|c|}
\hline 17. & $\begin{array}{l}\text { Pee, et al. } \\
(2010)\end{array}$ & Extended & \begin{tabular}{|l|} 
AF: perceived goal/task/reward \\
interdependence \\
KMC: knowledge sharing
\end{tabular} & $\begin{array}{l}\text { IS development project } \\
\text { performance }\end{array}$ & $\begin{array}{l}\text { Perceived goal/task/reward interdependence leads to } \\
\text { knowledge sharing between business and external } \\
\text { vendors, which in turn enhance project performance. }\end{array}$ \\
\hline 18. & $\begin{array}{l}\text { Joshi et al. } \\
(2010)\end{array}$ & Moderated & $\begin{array}{l}\text { KMC: knowledge creation } \\
\text { M: IT-enabled social integration }\end{array}$ & Innovation performance & $\begin{array}{l}\text { IT-enabled absorptive capacity (where knowledge } \\
\text { transformation /creation is a part) more strongly } \\
\text { contributes to innovative performance when IT-enabled } \\
\text { social integration is higher.I }\end{array}$ \\
\hline 19. & $\begin{array}{l}\text { Choi et al. } \\
(2010)\end{array}$ & Extended & $\begin{array}{l}\text { AF: Transactive Memory Systems } \\
\text { (TMS), IT support for KM } \\
\text { KMC: knowledge sharing }\end{array}$ & Team performance & $\begin{array}{l}\text { TMS and IT support affects knowledge sharing and } \\
\text { application, which in turn improves team performance. }\end{array}$ \\
\hline 20. & $\mid \begin{array}{lr}\text { Mills } & \text { and } \\
\text { Smith } & (2011)\end{array}$ & Basic & $\begin{array}{l}\text { AF: organizational structure, } \\
\text { technology, } \\
\text { KMC: knowledge application, } \\
\text { knowledge conversion }\end{array}$ & $\begin{array}{l}\text { organizational } \\
\text { performance }\end{array}$ & $\begin{array}{l}\text { Knowledge resources (e.g. organizational structure, } \\
\text { knowledge application) are directly related to } \\
\text { organizational performance, while others (e.g. } \\
\text { technology, knowledge conversion), though important } \\
\text { preconditions for } \mathrm{KM} \text {, are not directly related to } \\
\text { organizational performance. }\end{array}$ \\
\hline 21. & \begin{tabular}{|l} 
Lee et \\
$(2012)$
\end{tabular} & Moderated & $\begin{array}{l}\text { AF: collaboration, learning culture, } \\
\text { top management support, and IT } \\
\text { support } \\
\text { KMC: knowledge process } \\
\text { capabilities }\end{array}$ & $\begin{array}{l}\text { Organizational } \\
\text { performance. }\end{array}$ & $\begin{array}{l}\text { Collaboration, learning culture, top management } \\
\text { support, and IT support affect the knowledge process } \\
\text { capabilities. Knowledge process capabilities and } \\
\text { creative organizational learning in turn mediate the } \\
\text { relationship between KM infrastructure and } \\
\text { organizational performance, which demonstrate the } \\
\text { relevance of KM infrastructure for organizational } \\
\text { performance. }\end{array}$ \\
\hline 22. & $\mid \begin{array}{l}\text { Tseng and } \\
\text { Lee (2014) }\end{array}$ & Moderated & KMC & $\begin{array}{l}\text { technology, knowledge } \\
\text { conversion }\end{array}$ & $\begin{array}{l}\text { Dynamic capability is an important intermediate } \\
\text { organizational mechanism through which the benefits } \\
\text { of KM capability are converted into performance effects } \\
\text { at the corporate level. }\end{array}$ \\
\hline
\end{tabular}




\section{The Knowledge-Based View of the Impact of $K M$}

The emergence of the "knowledge-based view" (KBV) as a preeminent school of strategic management (Spender and Grant, 1996) has provided a new lens with which to view issues and implications associated with knowledge resource and performance. Based on Table 1 literature, Figure 1a displays the empirical studies cited above. These studies are selected based on the KM capability and the related empirical findings. We therefore argue that organizations with higher levels of $\mathrm{KM}$ capabilities are able to rapidly adjust their knowledge based on various areas to facilitate knowledge documentation, acquisition, sharing, and creation, to enhance organizational performance. Thus, we propose $\mathrm{H}_{1}$.

\section{H1 KBV Model: KMC-Performance model}

$\mathrm{H}_{1}$ : Higher levels of knowledgemanagement capability are associated with higher levels of financial and managerial performance.

\section{The Industrial factors of the Impacts of $K M$}

Three of the studies in Figure $1 \mathrm{~b}$ (Gold et al., 2001; Cui et al., 2005; Liu and Tsai, 2007) test the association between "industrial factors" and "KM capability," and the association was found to be significant in each of the studies. Competitive intensity refers to the degree to which a firm faces competition in a market (Grewal and Tansuhaj, 2001; Jaworski and Kohli, 1993). Liu and Tsai (2007) think internal business process is an important enabler for KM capability. As such, it can be argued that in an industry characterized by Porter's (1979) five competitive forces, an organization strives to develop greater knowledgemanagement capability to enhance its understanding of customer needs, and thus enable itself to provide customers with unique benefits. The following hypotheses are made:
$\mathrm{H}_{\text {2a-1: }}$ : Operational complexity in the industrial environment is positively related to knowledge-management capability.

$\mathrm{H}_{2 \mathrm{a}-2}$ : Competitive intensity in the market environment is positively related to knowledge-management capability.

$\mathrm{H}_{2 \mathrm{a}-3}$ : Business process complexity in the market environment is positively related to knowledge-management capability.

$\mathrm{H}_{2 \mathrm{a}-4}$ : Production complexity in the market environment is positively related to knowledge-management capability.

Industry dimension focuses on factors at the industry level. One can imagine that the same KM capability might have different values for different industries. Eisenhardt and Tabrizi (1995) find some evidence to the moderating impact of uncertainty (in the form of unpredictable products) on the relationship between supplier involvement and product performance (in the form of speed of product development). We posit hypotheses to reflect the moderated models and to evaluate how they might provide different insight. The first set is intended to test the industrial factors as moderators in hypotheses $\mathrm{H}_{2 \mathrm{~b}-1}$ to $\mathrm{H}_{2 \mathrm{~b}-4}$, respectively. The following hypotheses express this:

$\mathrm{H}_{2 \mathrm{~b}-1}$ : The greater the operational complexity of the organization, the more KM capabilities improves its financial and managerial performance.

$\mathrm{H}_{2 b-2}$ : The greater the level of competition in the industry, the more KM capabilities improves its financial and managerial performance.

$\mathrm{H}_{2 \mathrm{~b}-3}$ : The greater the business process complexity of the organization, the more KM capabilities improves its financial and managerial performance.

$\mathrm{H}_{2 \mathrm{~b}-4}$ : The greater the production complexity of the organization, the more KM capabilities improves its financial and managerial performance. 


\section{The Management factors of the Impacts of KM}

Cui et al. (2005), as listed in Figure 1b, test the direct association between "market dynamisms" and "KM capability," and found those associations to be statistically significant. Market dynamisms may cause changes in the industrial structure of knowledge economics. Market dynamism refers to the degree of change in the market (Jap, 1999). As such, we argue that in highly dynamic market environments, organizations develop greater knowledgemanagement capability to serve their markets more effectively. Formally, the hypothesis made is the following:

$\mathrm{H}_{3 \mathrm{a}-1}$ : Market dynamism in the market environment is positively related to organizational knowledge-management capability.

Some studies in Figure $1 \mathrm{~b}$ (Lee and Choi, 2003; Gold et al., 2001; Napaporn and Phapruke, 2008) point out that leadership establish enabling conditions for achieving organizational outcome through the knowledge-management capability. Leadership is an important factor of KM (Holsapple and Joshi, 2000; Skyrme and Amidon, 2000; Choi and Lee, 2003; Herder et al., 2003). Ruggles (1998) concludes that the main barriers to implementing knowledge management are all people related. We build the following hypothesis:

$\mathrm{H}_{3 a-2}$ : Leadership style is positively related to organizational knowledge-management capability.

The four studies in Figure 1b (Gold et al., 2001; Fedor et al., 2003; Kulkarni et al., 2006-2007; Juntarung and Ussahawanitchakit, 2008) that tested the relationship between "support" and "knowledge-management capability" find the association to be significant. Many researchers have found that organizational support is the critical success factor for KM. While senior manager support is significant at the main-effect level, its role is also best seen together with explicit knowledge dissemination of KM Capability (Fedor et al., 2003). Thus, the following hypothesis is formed.

$\mathrm{H}_{3 a-3}$ : Organizational IT support from senior manager is positively related to knowledge management capability.

Five studies in Figure 1c indicate market dynamisms to be a moderator. Dynamic markets influence firm operations and demand that firms be able to adjust quickly for success (Jap, 1999). In highly dynamic markets, frequent changes in customer demand, technology, and business practices require firms to continually modify their products or services to remain competitive. Market dynamism refers to the variability and unpredictability of customer preferences and expectations (Gatingnon and Xuereb, 1997). Alternatively, in less dynamic markets, customer demand is relatively stable, and therefore less product or service modifications are required. Knowledge-management capabilities provide firms the ability to be sensitive to market information, to react to environmental change, and to continually modify organizational routines. The following hypothesis is thus made:

$\mathrm{H}_{3 \mathrm{~b}-1}$ : The greater the market dynamism of the organization, the more KM capabilities improves its financial and managerial performance.

Following Attharangsun and Ussahawanitchakit (2008), research in Figure $1 \mathrm{c}$ is associated with the leadership and KM capability literature. Support is more likely to exist when the CEO and other top managers are aware of the assets and opportunities that exist within the company (Kearns, 2006). Furthermore Support is more likely to exist when the chief executive officer (CEO) and other top managers are aware of the assets and opportunities that exist within the company (Kearns, 2006). This study says top management support also exists when the top management is aware of the IT-related assets and opportunities that exist within the company 
to support efficiency. This study proposes top-management IT support as a moderator.

$\mathrm{H}_{3 \mathrm{~b}-2}$ : The greater support from the organization, the more KM capabilities improves its financial and managerial performance.

Leadership is an important factor affecting KM (Holsapple and Joshi, 2000; Skyrme and Amidon, 2000; Choi and Lee, 2003; Herder et al., 2003). Some studies point out that organizational properties are the source of some of the barriers to KM. For example, Ruggles (1998) concludes that the main barriers to implementing knowledge management - such as a culture that inhibits knowledge sharing, lack of leadership by top management, and poor understanding of what KM involves -- are all people related. Lee and Choi (2003) think people are at the heart of creating organizational knowledge. This study proposes leadership style as a moderator. Therefore,

$\mathrm{H}_{3 \mathrm{~b}-3}$ : The greater the openness of leadership style of the organization, the more KM capabilities improves its financial and managerial performance.

\section{The IT Readiness factors of the Impacts of KM}

The 10 studies in Figure $1 \mathrm{~b}$ test the association between IT level and KM capability and show significant effect. Technological capability refers to the roots of a firm's long-term competitive advantage (Lee et al., 2001; Lee and Choi, 2003). Tanriverdi (2005) also indicates that IT relatedness of the firm's business units enhances cross-unit KM capability; KM capability leads to superior firm performance. Among technology-related variables, this study focuses on IT support. That is, KM allows an organization to document, acquire, share, and apply knowledge. Thus, we hypothesize:

$\mathrm{H}_{4 a}$ : IT readiness is positively related to knowledge management capability.
This study proves that the IT-application moderating effect of the relationships between knowledge-management capability and performances is weaker in highly dynamic market. When competitors introduce new products using new technologies at a rapid pace, thereby increasing the level of product variety, it forces all manufacturers to respond strategically or put themselves in the strategic position of being able to respond to such changes. Gandhi (2004) suggests that information technology is not the heart of knowledge management, adding it only plays a supporting role in knowledge management. People have to determine whether information is appropriate and addresses a need. The anticipated relation from knowledge-management capability and market intelligence are both weaker under technology level, leading to the following hypothesis.

$\mathrm{H}_{4 b}$ : The greater the level of IT readiness in the organization, the more KM capabilities improves its financial and managerial performance.

\section{Methodology}

To test the proposed moderated model and compare it with the prevailing RBV model, we conducted a survey of business firms in Taiwan.

\section{Measurement}

A survey instrument was developed to collect data for the study. All the constructs were measured using a five-point Likert scale ranging from 1 (strongly disagree) to 5 (strongly agree).

\section{KM Capabilities}

Knowledge documentation was measured in terms of its definition as acts to record, store, encode, convert, cite, externalize, or annotate actions, knowledge and conclusions (Holsapple and Singh, 2001; Lee and Choi, 2003). 
Knowledge acquisition was measured in terms of its definition as acts to locate, retrieve, or obtain facts, information, and knowledge. Specific capabilities include internal training, collection of experiences of experts, and external training (Holsapple and Singh, 2001; Lee and Choi, 2003).

Knowledge sharing is defined as acts involving joint use of resources, transfer and distribution of information, and exchange of knowledge. Specific capabilities include those to use email and computer-supported work flows (Holsapple and Singh, 2001; Lee and Choi, 2003).

Knowledge creation was measured in terms of its definition as acts to assemble, combine, construct, or design knowledge and solutions. Specific capabilities include the use of databases, Internet, data mining, and decision support systems (Gold et al., 2001; Holsapple and Singh, 2001; Lee and Choi, 2003).

\section{Contingency Factors}

Operational complexity and competition refer to Porter's (1979) five competitive forces. Operational complexity was measured as the buyer's propensity to substitute, the perceived level of product differentiation, the existence of barriers to entry, and variations in government policies (law). Competition was measured in terms of its definition as the number of competitors, buyer switching costs, and the availability of existing substitute products.

Business process complexity refers to the stages of the value chain (Porter, 1985) and was measured in terms of its definition as knowledge needs in inbound logistics, operation, outbound logistics, marketing and sales, and customer services.

Production complexity was measured in terms of knowledge needs in product use, raw material procurement, manufacturing, and research and development (R\&D).

Market orientation, a concept derived from the study by Slater and Narver (1995), was measured as the degree to which the firm places the highest priority on the profitable creation and maintenance of superior customer value, and provides norms for behavior regarding the organizational development of, and responsiveness to, market information.

Leadership style was adapted from the study by Likert (1967). It was measured in terms of its definition as the degree of "openness" or participatory democracy in terms of freedom to express suggestions and encourage communication among employees. It was also measured as the degree to which employees have the right to participate in decision making.

IT senior management support was adapted from the study by Premkumar and Roberts (1999). It was measured in terms of its definition as the degree of support from senior management for the adoption of new technologies, the degree to which adequate resources are allocated for the adoption of new technology, and the degree to which employees are encouraged to use new technologies.

IT readiness were measured following the method suggested by Davenport (1997) in his case study, which suggests that the level of information technology application can be measured in terms of hardware, software, and systems capabilities.

\section{Organizational Performance}

The dependent variable in the model is organizational performance: Financial assessments were measured with ROA (return on assets) and ROS (return on sales) (Lee and Choi, 2003); managerial performance measures included operating performance outcomes, innovation, and customer satisfaction (Lee and Choi, 2003). The study assessed the financial performance and managerial performance outcomes over the past three years. The scale ranged from 1 (significantly decreasing) to 5 (significantly increasing). 


\section{Pretest}

A pretest of the instrument was conducted using three academic domain experts and five practicing managers in a focus group. The pretest assessed the face validity and content validity of the operational measures, and ensured that informants would understand the instructions, items, and response scales of the study in the intended ways. Minor modifications were made based on the suggestions received.

\section{Survey Instrument Distribution and Sample Profiles}

Three channels were used to distribute the survey instruments for the study. In the first wave of data collection, survey instruments were distributed by mail to business executives at large enterprises. The cover letter requested the CKO (chief knowledge officer) or $\mathrm{ClO}$ (chief information officer) to fill out and return the instrument. Of the 1,116 survey questionnaires mailed, $161 \mathrm{got}$ usable responses (resulting in an effective response rate of $15.7 \%$ ). At approximately the same time, 778 instruments were distributed to practitioners attending a $\mathrm{KM}$ conference, with 74 usable ones being returned (resulting in an effective response rate of $9.5 \%$ ). In a third wave, 39 usable instruments were collected through email from practitioner-users who had learned about the survey from a university-based web site message. (It was not possible to calculate a response rate for the third wave.)

Hence, we pooled the data in our data analysis. Table 2 summarizes the characteristics of the sample. Overall, the sample of respondents seemed to be rather diverse, but there was a preponderance of manufacturing firms.

\section{Table 2 - Demographics of Sample}

\begin{tabular}{|c|c|c|c|c|c|}
\hline Industry & Frequency & Percent & Assets (US\$) & Frequency & Percent \\
\hline Traditional & 131 & 52.0 & Less than 0.6 million & 60 & 23.8 \\
\hline Manufacturing & & & $0.6-3$ million & 58 & 23.0 \\
\hline High-Tech & 41 & 16.3 & $3-30$ million & 62 & 24.6 \\
\hline Manufacturing & & & Greater than 30 million & 62 & 24.6 \\
\hline Services & 80 & 31.7 & Missing value & 10 & 4.0 \\
\hline Total & 252 & 100.0 & Total & 252 & 100.0 \\
\hline
\end{tabular}

\section{Data Analysis and Empirical Results}

\section{Reliability and Validity}

Item analyses were performed with Cronbach Alpha coefficients for all multiitem scale measures. The reliabilities of the measure for the constructs are shown in Table 3. As the literature indicates that an alpha coefficient above 0.6 is acceptable, the reliability of the multi-item scale is satisfactory (Nunnally, 1967). Therefore, all scales show acceptable reliability for further analysis.

Factor analysis was used to assess construct validity. The primary criterion for discriminant validity is that each indicator must load more highly on its associated construct than on any other construct. To determine loadings, the factorial composition of the variable scale items was tested using principal components analysis with varimax rotation. Table 4 shows these results for the main effect factors, and Table 5 shows them for the contingency variables.

For testing main effect factors and contingency factors using a 0.5 criterion for a significant item loading on a factor, the result shows that all items within each index are represented by a single factor, and the items of each factor do not confound with the items in other factors. A single scale for each research variable was constructed by averaging scores of a respondent over the items measuring each variable. 


Table 3 - Cronbach Alpha Coefficients
\begin{tabular}{|l|c|c|c|c|}
\hline Factors & Mean & Standard Deviation & No. of Items & Reliability Alpha coefficient \\
\hline Operational complexity, OC & 3.04 & 0.63 & 4 & 0.62 \\
\hline Competition, CT & 3.52 & 0.73 & 3 & 0.65 \\
\hline Business Process complexity, BP & 3.54 & 0.66 & 5 & 0.65 \\
\hline Production complexity, PC & 3.47 & 0.70 & 4 & 0.86 \\
\hline Market dynamism, MD & 3.81 & 0.60 & 4 & 0.75 \\
\hline Leadership style, LS & 3.71 & 0.68 & 3 & 0.78 \\
\hline IT support, ITS & 3.54 & 0.57 & 3 & 0.77 \\
\hline IT readiness, ITR & 3.75 & 0.66 & 4 & 0.86 \\
\hline Knowledge Documentation, DOC & 3.32 & 0.87 & 4 & 0.86 \\
\hline Knowledge Acquisition, ACQ & 3.32 & 0.88 & 4 & 0.87 \\
\hline Knowledge Sharing, SHA & 3.28 & 0.97 & 2 & 0.62 \\
\hline Knowledge Creation, CRE & 2.71 & 0.94 & 3 & 0.87 \\
\hline Managerial performance, MP & 3.42 & 0.64 & 4 & 0.78 \\
\hline Financial performance, FP & 3.10 & 1.00 & 2 & 0.85 \\
\hline
\end{tabular}

\section{Table 4 - Factor Loadings of Main Effect Variables (Number of Factors to Extract, 6)}

\begin{tabular}{|c|c|c|c|c|c|c|}
\hline & Documentation & Creation & Acquisition & Managerial performance & Financial performance & Sharing \\
\hline DOC1 & 0.822 & 0.081 & 0.220 & 0.160 & 0.041 & 0.205 \\
\hline $\mathrm{DOC2}$ & 0.791 & 0.233 & 0.131 & 0.201 & 0.032 & 0.152 \\
\hline DOC3 & 0.752 & 0.214 & 0.201 & 0.139 & 0.187 & 0.036 \\
\hline DOC4 & 0.658 & 0.037 & 0.301 & 0.084 & 0.084 & 0.288 \\
\hline CRE1 & 0.140 & 0.873 & 0.148 & 0.121 & 0.072 & 0.150 \\
\hline CRE2 & 0.149 & 0.851 & 0.169 & 0.051 & 0.103 & 0.195 \\
\hline CRE3 & 0.219 & 0.587 & 0.277 & 0.169 & 0.122 & 0.426 \\
\hline ACQ1 & 0.333 & 0.286 & 0.714 & 0.128 & 0.123 & 0.024 \\
\hline$A C Q 2$ & 0.332 & 0.097 & 0.698 & 0.131 & 0.030 & 0.482 \\
\hline ACQ 3 & 0.276 & 0.089 & 0.681 & 0.160 & 0.001 & 0.457 \\
\hline ACQ 4 & 0.212 & 0.435 & 0.676 & 0.218 & 0.209 & -0.028 \\
\hline MPE1 & 0.019 & -0.027 & 0.199 & 0.776 & 0.205 & 0.230 \\
\hline MPE2 & 0.192 & 0.064 & 0.186 & 0.771 & 0.157 & 0.172 \\
\hline MPE3 & 0.158 & 0.137 & -0.078 & 0.698 & 0.038 & 0.081 \\
\hline MPE4 & 0.192 & 0.191 & 0.288 & 0.603 & 0.220 & -0.173 \\
\hline FPE1 & 0.116 & 0.106 & 0.072 & 0.180 & 0.894 & 0.081 \\
\hline FPE2 & 0.094 & 0.109 & 0.101 & 0.229 & 0.878 & 0.079 \\
\hline SHE1 & 0.232 & 0.241 & 0.115 & 0.183 & 0.102 & 0.675 \\
\hline SHE2 & 0.241 & 0.413 & 0.148 & 0.101 & 0.089 & 0.638 \\
\hline eigen value & 2.965 & 2.539 & 2.455 & 2.421 & 1.839 & 1.829 \\
\hline \begin{tabular}{|l} 
Variance $(\%)$ \\
\end{tabular} & 15.6 & $\begin{array}{l}13.4 \\
\end{array}$ & 12.9 & 12.7 & 9.7 & 9.6 \\
\hline $\begin{array}{l}\text { Accumulated } \\
\text { variance }(\%)\end{array}$ & 15.6 & 29 & 41.9 & 54.6 & 64.3 & 73.9 \\
\hline
\end{tabular}

Notes: Extraction Method: Principal Component Analysis.

Rotation Method: Varimax with Kaiser Normalization.

\section{Relationships between Contingency Factors and Organizational Performance}

As variable correlation is a criterion for assessing moderating effects, Pearson correlation analysis was used to assess the relationships among factors. Table 6 presents the correlation matrix for the research variables. There were statistically significant positive relationships between
KM capabilities, contingency factors, and business performances.

From Table 6, market dynamism, leadership style, IT senior support, and IT readiness showed higher correlation with KM capabilities, while operational complexity, competition, business process complexity, and production complexity had low correlation with KM capabilities. According to Carte and Russell (2003), error 3 
resulting from high variable correlation should be avoided. Therefore, equations 5-6 were used to partial out $\mathrm{X}^{2}$ effects when those highly correlated variables were analyzed.

\begin{tabular}{|c|c|c|c|c|c|c|c|c|}
\hline & $\begin{array}{c}\text { Business } \\
\text { process } \\
\text { complexity }\end{array}$ & IT readiness & $\begin{array}{c}\text { Marketing } \\
\text { strategy }\end{array}$ & $\begin{array}{l}\text { Production } \\
\text { complexity }\end{array}$ & Leadership & Competition & $\begin{array}{l}\text { Operational } \\
\text { Complexity }\end{array}$ & $\begin{array}{c}\text { IT } \\
\text { strategy }\end{array}$ \\
\hline BP 1 & 0.779 & 0.148 & 0.196 & 0.089 & 0.041 & 0.035 & 0.084 & 0.090 \\
\hline BP 2 & 0.774 & 0.085 & 0.164 & 0.151 & 0.047 & 0.057 & 0.150 & 0.010 \\
\hline BP 3 & 0.768 & 0.078 & -0.005 & 0.128 & 0.135 & 0.114 & 0.123 & 0.053 \\
\hline BP 4 & 0.727 & 0.014 & -0.001 & 0.275 & 0.149 & 0.025 & 0.096 & 0.062 \\
\hline BP 5 & 0.647 & 0.016 & 0.167 & 0.358 & 0.060 & 0.079 & 0.049 & -0.061 \\
\hline ITR 1 & -0.041 & 0.832 & 0.171 & 0.123 & 0.029 & -0.025 & 0.051 & -0.053 \\
\hline ITR 2 & 0.117 & 0.807 & 0.049 & -0.015 & 0.093 & -0.021 & 0.007 & 0.108 \\
\hline ITR 3 & 0.179 & 0.794 & 0.099 & -0.034 & -0.013 & 0.032 & 0.102 & 0.159 \\
\hline ITR 4 & 0.184 & 0.784 & -0.060 & -0.083 & 0.059 & 0.007 & 0.105 & 0.219 \\
\hline ITR 5 & -0.122 & 0.681 & 0.230 & 0.161 & 0.009 & -0.008 & 0.045 & -0.217 \\
\hline MD 1 & 0.039 & 0.115 & 0.823 & 0.127 & 0.101 & -0.081 & -0.006 & 0.084 \\
\hline MD 2 & 0.114 & 0.047 & 0.785 & -0.030 & 0.161 & -0.020 & 0.149 & 0.003 \\
\hline MD 3 & 0.190 & 0.105 & 0.667 & 0.167 & 0.249 & -0.025 & -0.039 & 0.130 \\
\hline MD 4 & 0.065 & 0.113 & 0.561 & 0.046 & 0.124 & 0.278 & $\begin{array}{l}0.003 \\
\end{array}$ & -0.131 \\
\hline PC 1 & 0.167 & 0.086 & 0.077 & 0.738 & -0.010 & 0.020 & 0.137 & 0.051 \\
\hline PC 2 & 0.199 & 0.005 & 0.087 & 0.721 & -0.103 & -0.017 & 0.007 & 0.088 \\
\hline PC 3 & 0.349 & 0.019 & 0.079 & 0.595 & 0.202 & -0.039 & 0.192 & -0.183 \\
\hline PC 4 & 0.423 & -0.001 & 0.093 & 0.579 & 0.182 & -0.079 & 0.125 & 0.002 \\
\hline LS 1 & 0.076 & 0.030 & 0.115 & 0.052 & 0.819 & 0.010 & -0.002 & 0.053 \\
\hline LS 2 & 0.156 & 0.104 & 0.396 & 0.041 & 0.701 & -0.005 & 0.054 & -0.085 \\
\hline LS 3 & 0.220 & 0.043 & 0.367 & -0.024 & 0.687 & 0.046 & 0.047 & 0.175 \\
\hline CT 1 & 0.033 & -0.163 & 0.131 & -0.042 & -0.107 & 0.768 & 0.131 & 0.038 \\
\hline CT 2 & 0.195 & 0.024 & 0.073 & 0.037 & 0.000 & 0.766 & -0.021 & 0.059 \\
\hline CT 3 & -0.019 & 0.095 & -0.160 & -0.055 & 0.122 & 0.711 & -0.029 & -0.127 \\
\hline$O \mathrm{OC}_{1}$ & 0.178 & 0.079 & 0.074 & 0.185 & 0.013 & -0.050 & 0.781 & 0.142 \\
\hline OC 2 & 0.076 & 0.054 & -0.052 & 0.177 & 0.152 & 0.270 & 0.759 & 0.195 \\
\hline $\mathrm{OC} 3$ & 0.279 & 0.122 & 0.278 & -0.179 & -0.075 & -0.001 & 0.524 & -0.354 \\
\hline$\overline{O C} 4$ & 0.172 & 0.163 & 0.017 & 0.146 & -0.050 & -0.117 & 0.431 & -0.316 \\
\hline ITS 1 & 0.146 & 0.202 & 0.403 & 0.164 & 0.189 & -0.030 & 0.089 & 0.483 \\
\hline ITS 2 & 0.119 & 0.210 & 0.116 & 0.021 & 0.047 & -0.053 & 0.096 & 0.733 \\
\hline eigen value & 3.561 & 3.340 & 3.322 & 2.262 & 2.012 & 1.931 & 1.898 & 1.307 \\
\hline Variance $(\%)$ & 11.486 & 10.774 & 10.717 & 7.296 & 6.491 & 6.229 & 6.124 & 4.216 \\
\hline $\begin{array}{l}\text { Accumulated } \\
\text { variance }(\%)\end{array}$ & 11.486 & 22.260 & 32.977 & 40.273 & 46.764 & 52.993 & 59.117 & 63.333 \\
\hline
\end{tabular}

Notes: Extraction Method: Principal Component Analysis.

Rotation Method: Varimax with Kaiser Normalization.

\section{Table 6 - Descriptive Statistics \& Inter-Correlations for the Research Variables $(n=274)$}

\begin{tabular}{|c|c|c|c|}
\hline \multirow{2}{*}{ Contingency factors } & \multirow{2}{*}{ KM capabilities } & \multicolumn{2}{|c|}{ Performance } \\
\hline & & Financial performance, FP & Managerial performance, MP \\
\hline Operational complexity, OC & $0.227^{\star \star \star}$ & $0.163^{\star \star}$ & 0.109 \\
\hline Competition, CT & 0.068 & -0.090 & -0.048 \\
\hline Business Process complexity, BP & $0.255^{\star \star \star}$ & $0.159^{\star *}$ & $0.223^{\star \star \star}$ \\
\hline Production complexity, PC & $0.234^{* * *}$ & $0.211^{* * *}$ & $0.301^{* * *}$ \\
\hline Market dynamism, MD & $0.395^{\star \star *}$ & $0.246^{\star \star \star}$ & $0.360^{\star \star \star}$ \\
\hline Leadership style, LS & $0.351^{* \star *}$ & $0.130^{*}$ & $0.262^{\star \star *}$ \\
\hline IT support, ITS & $0.589^{\star \star \star *}$ & $0.337^{\star * \star}$ & $0.467^{\star \star \star}$ \\
\hline IT readiness, ITR & $0.686^{\star \star \star}$ & $0.204^{\star *}$ & $0.373^{\star \star \star}$ \\
\hline KM capability, KMC & $1^{* * *}$ & $0.361^{* * *}$ & $0.491^{* * *}$ \\
\hline
\end{tabular}

Notes: The significance of the correlation coefficients is indicated as: ${ }^{* * *}: p \leq 0.001 ;{ }^{* *}: p \leq 0.01 ;{ }^{*}: p \leq 0.05$ 


\section{Testing the Extending Model from Resource-Based View}

The basic model and extended model shown in Figure 1 were tested. As noted, the paths between KM capabilities and performance were positive and had high magnitude. This implied that KM capabilities contributed to the achievement of managerial performance and financial performance. The purpose of this test was to show that our data generate results that were consistent with prior findings using the RBV model. Hence, the difference between our proposed moderated model and the basic/extended model would not be due to data collection. This also allowed us to determine the degree of additional insight that the moderated model may reveal.
To test the hypotheses, we used hierarchical regression analysis. The eight contingent variables were entered separately as enablers that affect KMC and, in turn, organizational performance. Table 7 shows the regression coefficients of the basic and extended models. As hypothesized (H1a), KM capabilities do have a significant positive relationship with both performances. The coefficient of determination (R2) for managerial performance was 0.253 and for financial performance was 0.133 . The relative lower R2 on financial performance was also understandable as there were so many factors that may have contributed to changes in financial performance. In general, the findings were consistent to those reported in prior research, as outlined in Table 1.

\section{Table 7 - Result of Regression Analyses for Main Effect}

\begin{tabular}{|c|c|c|c|c|}
\hline Dependent factor & Independent factor & $\beta$ of independent factor & $F$ value & $R^{2}$ \\
\hline \multirow{2}{*}{$\begin{array}{l}\text { Managerial } \\
\text { performance }\end{array}$} & Constant & $5.727^{* * *}$ & \multirow[t]{2}{*}{$88.103^{* * *}$} & \multirow[t]{2}{*}{0.253} \\
\hline & KM capability & $1.134^{* * *}$ & & \\
\hline \multirow{2}{*}{$\begin{array}{l}\text { Financial } \\
\text { performance }\end{array}$} & Constant & $2.699^{* \star *}$ & \multirow[t]{2}{*}{$40.661 * * *$} & \multirow[t]{2}{*}{0.133} \\
\hline & KM capability & $0.824^{* * *}$ & & \\
\hline \multirow[t]{9}{*}{ KM capability } & Constant & -0.433 & \multirow[t]{9}{*}{$41.389 * * *$} & \multirow[t]{9}{*}{0.555} \\
\hline & Operational complexity (OC) & -0.114 & & \\
\hline & Competition (CT) & 0.076 & & \\
\hline & Business Process complexity (BP) & -0.431 & & \\
\hline & Production complexity (PC) & $0.111^{*}$ & & \\
\hline & Market dynamism (MD) & $0.145^{\star *}$ & & \\
\hline & Leadership style (LS) & $0.160^{* *}$ & & \\
\hline & IT support (ITS) & 0.121 & & \\
\hline & IT readiness (ITR) & $0.513^{* \star *}$ & & \\
\hline
\end{tabular}

Notes: ${ }^{*} p \leq 0.05 ;{ }^{* *} p \leq 0.01 ;{ }^{* * *} p \leq 0.001$

For RBV model analysis, as shown in Table 7 , three factors had significant positive effects on KMC, namely, production complexity, market dynamism, and leadership style. That is, hypothesis $\mathrm{H}_{1 a}$ was partially supported. This result is consistent with prior literature.

\section{Testing the Moderation Model from Contingency Theory View}

The moderated model that treats contingent factors as moderators shown in Figure 1c was tested in this section. Tables 8 and 9 show the results of introducing multiple contingency factors into the regression equations for managerial and financial performance, respectively.

The moderators were treated as quantitative variables in this study. To improve on the assessment of moderator variables, we devised a systematic method for moderator analysis. The analysis carried out here was designed to respond to the study by Sharma et al. (1981) and Carte and Russell (2003) for assessing moderating effects. 
Sharma, et al (1981) has identified three different types of moderators, as shown in Figure 2. Moderated Multiple Regression (MMR) was used to test the relationship between antecedent and dependent variables. Three moderated regression analyses (MRA) were performed for distinguishing the variable as Figure 2 (quadratic 1-4). The modified procedures described here focused on each potential moderator and use MRA, subgroup analysis, and multicolinearity effects to determine whether the focal variable is a moderator, and if so, identify which type of moderator it was - pure, quasi, or homologizer.

\begin{tabular}{|c|c|c|}
\hline & Related to criterion and/or antecedent $(c \neq 0)$ & Not related to criterion and/or antecedent $(c=0)$ \\
\hline $\begin{array}{l}\text { No interaction with } \\
\text { antecedent } \\
(d=0)\end{array}$ & $\begin{array}{c}(1) \\
\text { Antecedent, } \\
\text { Intervening } \\
\text { Suppressor } \\
\mathrm{P}=\mathrm{a}+\mathrm{b}^{*} \mathrm{KMC}+\mathrm{c}^{*} \text { Moderator }+\varepsilon\end{array}$ & $\begin{array}{c}(2) \\
\text { Moderator } \\
\text { (Homologizer) } \\
\mathrm{P}=\mathrm{a}+\mathrm{b}^{*} \mathrm{KMC}+\varepsilon z\end{array}$ \\
\hline $\begin{array}{l}\text { Interaction with } \\
\text { antecedent } \\
(\mathrm{d} \neq 0)\end{array}$ & $\begin{array}{c}\text { (3) } \\
\text { Moderator } \\
\text { (Quasi Moderator) } \\
P=a+b^{*} K M C+c^{*} \text { Moderator } \\
+d K M C^{*} \text { Moderator }+\varepsilon\end{array}$ & $\begin{array}{c}(4) \\
\text { Moderator } \\
\text { (Pure Moderator) } \\
\mathrm{P}=\mathrm{a}+\mathrm{b}^{*} \mathrm{KMC}+\mathrm{dKMC} \text { Moderator }+\varepsilon\end{array}$ \\
\hline
\end{tabular}

\section{Figure 2 - Typology of Specification Variables}

A review done by Carte and Russell (2003) has revealed nine common errors often committed by IS researchers in investigating moderator relationships. Carte and Russell (2003) initially tested whether the variance explained by the moderated effects was significant beyond the main effect.

The basic rationale of the method was that we should look at not only the regression coefficient of the interaction term but also the explanatory power of the model. The model with a significantly higher $\mathrm{R}^{2}$ should be chosen because it is considered to be more powerful. This alleviates the first error identified by Carte and Russell (2003). An F test was needed to distinguish if there was a significant $R^{2}$ difference between two equations. An $F$ statistic was significantly greater than 1 , leading to the rejection of $\mathrm{H}_{0}$ : $\Delta \mathrm{R}^{2}=0$, (i.e., $R_{3}^{2}-R_{2}^{2}$ ), and the conclusion was that either $Z$ moderates the $X \rightarrow Y$ relationship, or it does not.
Where, $F_{\left(d f_{3}-d f_{2}, N-d f_{3}-1\right)}=\frac{\Delta R^{2} /\left(d f_{3}-d f_{2}\right)}{\left(1-R_{3}^{2}\right) /\left(N-d f_{3}-1\right)}$.

Table 8 shows that production complexity has significant effect $(c=1.782, p<0.01)$ and interaction effect $(d=-0.058, p<0.05$, $\Delta R^{2}=1.6 \%$, and it has lower correlation with $\mathrm{KMC}$ (Table 6). Its $\mathrm{F}$ statistic on $\Delta \mathrm{R}^{2}$ was 6.25 , which was greater than 1 . Therefore, production complexity is identified as a quasi-moderator between KMC and managerial performance. This indicated that the impact of KMC on managerial performance existed but the degree of influence may vary under different levels of production complexity. This turned out to be the only significant contingent factor that moderated the KMC-managerial performance relationship. Business process complexity, market-dynamism, IT senior support strategy, and IT readiness were predictors for managerial performance. 


\begin{tabular}{|c|c|c|c|c|c|c|c|c|c|}
\hline \multirow[t]{2}{*}{ Effect } & \multicolumn{4}{|c|}{ Independent factor } & \multirow[t]{2}{*}{ F value } & \multirow[t]{2}{*}{$R^{2}$} & \multirow[t]{2}{*}{$\Delta R^{2}$} & \multirow[t]{2}{*}{$\mathrm{F}$ test } & \multirow{2}{*}{ Result } \\
\hline & Constant & KMC & Mod & KMCxMod & & & & & \\
\hline Mod & $5.616^{\star \star *}$ & $0.162^{* * *}$ & - & - & $91.921^{* * *}$ & 0.253 & - & - & $\begin{array}{l}\text { KMC has a significant positive } \\
\text { relationship with managerial } \\
\text { performance }\end{array}$ \\
\hline \multirow{2}{*}{$\mathrm{OC}$} & $5.616^{\star \star \star}$ & $0.162^{\star \star \star}$ & 0.0001 & - & $45.791^{\star \star \star}$ & 0.253 & - & \multirow{2}{*}{ ns } & \multirow{2}{*}{$O C$ has no effect } \\
\hline & $6.188^{* \star}$ & 0.137 & -0.192 & 0.008 & $30.466^{\star \star \star}$ & 0.253 & 0 & & \\
\hline \multirow{2}{*}{ CT } & $6.239^{* * *}$ & $0.163^{\star \star \star}$ & -0.188 & - & $47.306^{\star \star \star}$ & 0.259 & - & \multirow{2}{*}{ ns } & \multirow{2}{*}{ CT has no effect } \\
\hline & $5.141^{* *}$ & $0.211^{*}$ & 0.121 & -0.013 & $31.585^{\star * *}$ & 0.260 & 0.001 & & \\
\hline \multirow{2}{*}{$\mathrm{BP}$} & $4.743^{\star * \star}$ & $0.153^{\star \star \star}$ & $0.306^{*}$ & - & $48.940^{* * *}$ & 0.265 & - & \multirow{2}{*}{ ns } & \multirow{2}{*}{$\mathrm{BP}$ is a predictor } \\
\hline & $4.521^{*}$ & $0.263^{*}$ & 0.169 & -0.003 & $32.513^{* * \star}$ & 0.265 & 0 & & \\
\hline \multirow{2}{*}{ PC } & $4.173^{\star \star \star}$ & $0.146^{\star \star \star}$ & $0.517^{\star \star \star}$ & - & $56.136^{\star \star \star}$ & 0.293 & - & \multirow{2}{*}{$\begin{array}{c}6.25 \\
\text { (F test for judge } \Delta R^{2} \text { ) }\end{array}$} & \multirow{2}{*}{$P C$ is a Quasi moderator } \\
\hline & -0.164 & $0.345^{\star * *}$ & $1.782^{\star *}$ & $-0.058^{\star}$ & $40.182^{\star * \star}$ & 0.309 & 0.016 & & \\
\hline \multirow{2}{*}{ MD } & $4.063^{* \star \star}$ & $0.136^{* * *}$ & $0.564^{* *}$ & - & $53.699^{\star \star \star}$ & 0.284 & - & \multirow[t]{2}{*}{ 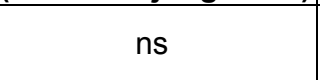 } & \multirow[b]{2}{*}{ MD is a predictor } \\
\hline & $4.215^{\star \star \star}$ & 0.051 & $0.520^{* *}$ & 0.04 & $36.043^{* \star *}$ & 0.286 & 0.002 & & \\
\hline \multirow{2}{*}{ LS } & $4.899^{\star \star \star}$ & $0.149^{\star \star \star}$ & 0.271 & - & $48.117^{\star \star \star}$ & 0.262 & - & \multirow{2}{*}{ ns } & \multirow{2}{*}{ LS has no effect } \\
\hline & $5.367^{* *}$ & 0.127 & 0.142 & 0.006 & $31.993^{* * *}$ & 0.262 & 0 & & \\
\hline \multirow{2}{*}{ ITS } & $3.763^{* \star *}$ & $0.109^{* * *}$ & $0.867^{* * *}$ & - & $59.914^{\star \star *}$ & 0.307 & - & \multirow{2}{*}{ ns } & \multirow{2}{*}{ ITS is a predictor } \\
\hline & $3.619^{* \star *}$ & 0.115 & 0.909 & -0.002 & $39.798^{* * *}$ & 0.307 & 0 & & \\
\hline \multirow{2}{*}{ ITR } & $3.874^{* \star *}$ & $0.134^{\star \star \star}$ & $0.635^{\star \star \star}$ & - & $58.550^{\star \star \star}$ & 0.302 & - & \multirow{2}{*}{ ns } & \multirow{2}{*}{ ITR is a predictor } \\
\hline & $2.371^{\star *}$ & $0.2^{*}$ & 1.045 & -0.018 & $39.168^{\star \star \star}$ & 0.303 & 0.001 & & \\
\hline
\end{tabular}

Notes: 1. Mod stands for moderator; Operational complexity (OC), Competition (CT), Business process complexity (BP), Production complexity

(PC), Market dynamism (MD), Leadership style (LS), IT support (ITS), and IT readiness (ITR)

2. $\mathrm{F}$ test was calculated by the equation below:

3. ${ }^{*} \mathrm{p} \leq 0.05 ;{ }^{* *} \mathrm{p} \leq 0.01 ;{ }^{* * *} \mathrm{p} \leq 0.001$

$$
F_{\left(d f_{m u l}-d f_{\text {add }}, N-d f_{\text {mul }}-1\right)}=\frac{\Delta R^{2} /\left(d f_{\text {mult }}-d f_{\text {add }}\right)}{\left(1-R_{\text {mult }}^{2}\right) /\left(N-d f_{\text {mult }}-1\right)}
$$




\begin{tabular}{|c|c|c|c|c|c|c|c|c|c|}
\hline Effect & \multicolumn{4}{|c|}{ Independent factor } & \multirow[t]{2}{*}{$F$ value } & \multirow[t]{2}{*}{$\mathrm{R}^{2}$} & \multirow[t]{2}{*}{$\Delta R^{2}$} & \multirow[t]{2}{*}{$\mathrm{F}$ test } & \multirow[t]{2}{*}{ Result } \\
\hline & constant & $\mathrm{KMC}$ & Mod & KMCxMod & & & & & \\
\hline Mod & $2.631^{* \star \star}$ & $0.117^{\star \star \star}$ & - & - & $41.768^{* \star *}$ & 0.133 & - & - & Significant main effect \\
\hline \multirow{2}{*}{$\mathrm{OC}$} & $2.050^{\star \star \star}$ & $0.111^{\star * \star}$ & 0.237 & - & $22.075^{\star * \star}$ & 0.140 & - & \multirow{2}{*}{ ns } & \multirow[t]{2}{*}{ OC has no effect } \\
\hline & $3.412^{\star \star \star}$ & 0.053 & -0.220 & 0.019 & $14.882^{* \star \star}$ & 0.142 & 0.002 & & \\
\hline \multirow{2}{*}{ CT } & $3.532^{* * *}$ & $0.120^{\star \star \star}$ & $-0.273^{*}$ & & $23.205^{\star * *}$ & 0.146 & - & \multirow[b]{2}{*}{ ns } & \multirow{2}{*}{ CT is a predictor } \\
\hline & $3.091^{* * *}$ & 0.139 & -0.149 & -0.039 & $15.440^{\star * *}$ & 0.146 & 0 & & \\
\hline \multirow{2}{*}{ BP } & $2.072^{* *}$ & $0.111^{* * *}$ & 0.196 & - & $21.760^{* \star *}$ & 0.138 & - & \multirow{2}{*}{ ns } & \multirow{2}{*}{$\begin{array}{l}\text { BP is a homologizer } \\
\text { (Subgroup analysis) }\end{array}$} \\
\hline & $4.162^{*}$ & 0.016 & -0.399 & 0.027 & $14.911^{* \star \star}$ & 0.142 & 0.004 & & \\
\hline \multirow{2}{*}{ PC } & $1.699^{\star *}$ & $0.107^{* \star *}$ & $0.344^{*}$ & - & $23.916^{\star \star \star}$ & 0.150 & - & \multirow{2}{*}{ ns } & \multirow{2}{*}{$\mathrm{PC}$ is a predictor } \\
\hline & $2.076^{* \star *}$ & 0.090 & 0.224 & 0.036 & $15.907^{* * *}$ & 0.151 & 0.001 & & \\
\hline \multirow{2}{*}{ MD } & $1.724^{\star *}$ & $0.102^{\star \star *}$ & 0.329 & - & $22.762^{\star \star \star}$ & 0.144 & - & \multirow{2}{*}{ ns } & \multirow{2}{*}{ MD has no effect } \\
\hline & $1.819^{\star \star}$ & 0.049 & 0.302 & 0.027 & $15.221^{* \star *}$ & 0.145 & 0.001 & & \\
\hline \multirow{2}{*}{ LS } & $2.679^{\star \star \star *}$ & $0.118^{\star \star \star}$ & -0.018 & - & $20.815^{\star \star \star}$ & 0.133 & - & \multirow{2}{*}{$\begin{array}{c}4.75 \\
\text { (F test for judge } \Delta R^{2} \text { of MRA) }\end{array}$} & \multirow{2}{*}{$\begin{array}{l}\text { LS is a quasi } \\
\text { moderator }\end{array}$} \\
\hline & $5.378^{\star *}$ & -0.012 & $-0.75^{\star}$ & $0.251^{*}$ & $14.986^{\star \star \star}$ & 0.143 & 0.015 & & \\
\hline \multirow[b]{2}{*}{ ITS } & $1.395^{*}$ & $0.082^{\star * *}$ & $0.578^{\star *}$ & - & $25.286^{\star * *}$ & 0.157 & - & \multirow{2}{*}{$\begin{array}{c}\text { Corr(KMC,ITS) high } \\
\text { (F test=0.32 for judge } \\
\text { multicollinearity) }\end{array}$} & \multirow[b]{2}{*}{ ITS is a suppressor } \\
\hline & $6.293^{* *}$ & -0.130 & -0.860 & $0.061^{*}$ & $18.736^{* * *}$ & 0.172 & 0.015 & & \\
\hline \multirow[b]{2}{*}{ ITR } & $2.030^{* *}$ & $0.107^{\star \star *}$ & 0.219 & - & $21.874^{* * *}$ & 0.139 & - & \multirow{2}{*}{$\begin{array}{c}\text { Corr (KMC,ITR) high, } \\
\text { ( } \mathrm{F} \text { test }=2.25 \text { for judge } \\
\text { multicollinearity }) \\
\left(\mathrm{F} \text { test }=7.25 \text { for judge } \Delta \mathrm{R}^{2} \text { of MRA }\right)\end{array}$} & \multirow[b]{2}{*}{$\begin{array}{l}\text { ITR is a quasi } \\
\text { moderator }\end{array}$} \\
\hline & $7.884^{\star \star \star}$ & -0.150 & $1.380^{*}$ & $0.069^{\star \star}$ & $17.396^{* \star \star}$ & 0.162 & 0.023 & & \\
\hline
\end{tabular}

Notes: 1. Mod stands for moderator; Operational complexity (OC), Competition (CT), Business process complexity (BP), Production complexity (PC), Market dynamism (MD), Leadership style (LS), IT support (ITS), and IT readiness (ITR)
2. $F$ test was calculated by the equation below:
$F_{\left(d f_{\text {mut }}-d f_{\text {add }}, N-d f_{\text {mut }}-1\right)}=\frac{\Delta R^{2} /\left(d f_{\text {mult }}-d f_{\text {add }}\right)}{\left(1-R_{\text {mult }}^{2}\right) /\left(N-d f_{\text {mult }}-1\right)}$

3. ${ }^{*} \mathrm{p} \leq 0.05 ;{ }^{* *} \mathrm{p} \leq 0.01 ;{ }^{* * *} \mathrm{p} \leq 0.001$ 
With respect to the KMC-financial performance relationship, Table 9 shows that both leadership style and IT readiness (ITR) were quasi moderators, but IT senior support (ITS) was a suppressor. Since ITS was highly correlated with $\mathrm{KMC}$ (Table 6), the coefficient of ITS $(c=0)$ and the coefficient of the interaction effect $(d=$ $0.061, p<0.05, \Delta R^{2}=2.3 \%$ in Table 9) were significant. The resulting $\Delta \mathrm{R}^{2}$ of multicolinearity effects testing that $F$ value was 0.32 (see Table 10), which was smaller than 1 , hence it was considered to be not a pure moderator but a suppressor.

Similarly, IT readiness (ITR) went through the same path as ITS due to its high correlation with $\mathrm{KMC}$, but its $\mathrm{F}$ statistic was significantly greater than 1 for multicollinearity effects testing and for equations 2 and 3 . Hence, the hypothesis $H_{0}: \Delta R^{2}=0$ is rejected (Carte and Russell, 2003, Error 7), and ITR is a quasimoderator. Another possibility that could have polluted the moderation effect was the high correlation between $X$ and $Z$. There was high multicollinearity $\left(r_{x z}\right)$ and possible nonlinear relationships between $\mathrm{Y}$ and $\mathrm{X}$, or $Y$ and $Z$ (Carte and Russell, 2003, Error 3). The results showed that ITS (IT support) factor had high correlation with KMC (shown in table 6). In this case, a significant $X Z$ (i.e., $\mathrm{KMC}^{*}$ ITR) term could be confound with a quadratic function of $\mathrm{X}$ or $\mathrm{Z}$ (i.e., $\mathrm{XX}$ or $\mathrm{ZZ}$ ). $F$ value was 2.25 for testing multicollinearity effect, as shown in Table 9. Another $F$ value was 7.25 for testing MRA equations. Therefore, ITS was defined as a quasivariable.

\section{Table 10 - F Statistics for Detecting Curvilinear Relationship between KMC and Financial performance}

\begin{tabular}{|c|c|c|c|c|}
\hline \multirow{2}{*}{ Moderator: Z } & \multicolumn{2}{|c|}{$\mathrm{R}^{2}$ of equation 5 and 6} & \multirow{2}{*}{$\Delta \mathrm{R}^{2}$} & \multirow{2}{*}{$\mathrm{F}$ test } \\
\hline & $\mathrm{R}^{2}$ of equation 5 & $\mathrm{R}^{2}$ of equation 6 & & \\
\hline IT support & 0.172 & 0.173 & 0.001 & 0.32 \\
\hline IT readiness & 0.164 & 0.171 & 0.007 & 2.25 \\
\hline
\end{tabular}

Notes: 1. KMC: Knowledge management capabilities

$$
\text { 2. F test was calculated by } F_{\left(d f_{\text {mult }}-d f_{\text {add }}, N-d f_{\text {mut }}-2\right)}=\frac{\Delta R^{2} /\left(d f_{\text {mult }}-d f_{\text {add }}\right)}{\left(1-R_{\text {mult }}^{2}\right) /\left(N-d f_{\text {mult }}-2\right)}
$$

The data in Table 9 show that business process complexity (BP) was a homologizer for financial performance because the significance of KMC disappears when the interaction term was introduced in equation 3 (i.e., both $c=0$ and $d=0$ ). Using the subgroup analysis procedure described by Hunt et al. (1975), the observations of business process complexity were divided into two subgroups using the median value (3.4) as the dividing point (with the median value in the higher group). Significant differences in two sub-groups noted in Table 11 were further analyzed to determine the exact nature of their impact. Table 12 presents the result of homologizer analysis. It shows that the low and high groups for business process complexity differed significantly with respect to KM capability and financial performance. The slope coefficients and $\mathrm{R}^{2}$ for every cell were statistically significant at the 0.05 level. The z-test was used to compare slope coefficient differences of two group samples. These results confirm the strength of the interaction effects found in the moderated regression analysis. Figure 3 illustrates the effect difference between the two subgroups. This result shows that KM capability had a positive relationship with financial performance in the higher business process complexity group. Other contingency factors, such as the degree of competition and production complexity, had no moderation effects and were predictors for financial performance. 


\begin{tabular}{l|l|c|}
\hline \multirow{2}{*}{ Table 11 - Pearson Correlation Coefficients in Two Groups } \\
\hline \multirow{2}{*}{ Contingent Factor } & \multicolumn{2}{|c|}{ Business Process Complexity } \\
\cline { 2 - 3 } & High group & Low group \\
\hline \multirow{2}{*}{ Financial Performance } & $\mathrm{n}=167$ & $\mathrm{n}=107$ \\
\cline { 2 - 3 } & $0.210^{*}$ & -0.011 \\
\hline
\end{tabular}

Notes: * $p \leq 0.05$;

\section{Table 12 - Slope Coefficients for Split Samples: KMC on Financial Performance}

\begin{tabular}{|l|l|c|c|c|r|r|}
\hline \multirow{2}{*}{ Criterion factors } & \multirow{2}{*}{ Contingency Factors } & \multicolumn{2}{|c|}{ Slope ${ }^{\mathrm{a}}$} & \multicolumn{2}{|c|}{ Standard error } & \multirow{2}{*}{$\mathrm{Z}$ test $\mathrm{b}$} \\
\cline { 3 - 6 } & & Low & High & Low & High & \\
\hline Financial performance & Business Process complexity & $0.522^{*}$ & $-0.16^{*}$ & 0.15 & 0.03 & 4.445 \\
\hline
\end{tabular}

Notes: a Two separate equations were obtained, one for the low (below the median) group, the other for the high (equal to or above the median) group. Slope coefficients (non-standardized beta weights) for low and high moderator groups are significantly ( 0.01 or lower) different for the independent variable.

b $z=\frac{\left(b_{1}-b_{2}\right)}{\sqrt{s e_{b 1}^{2}+s e_{b 2}^{2}}}$

(b: slope coefficient, se: standard error)

${ }^{c} z>1.96$, i.e. two slops of two regressions are difference.

*Significant at the 0.05 level (2-tailed)

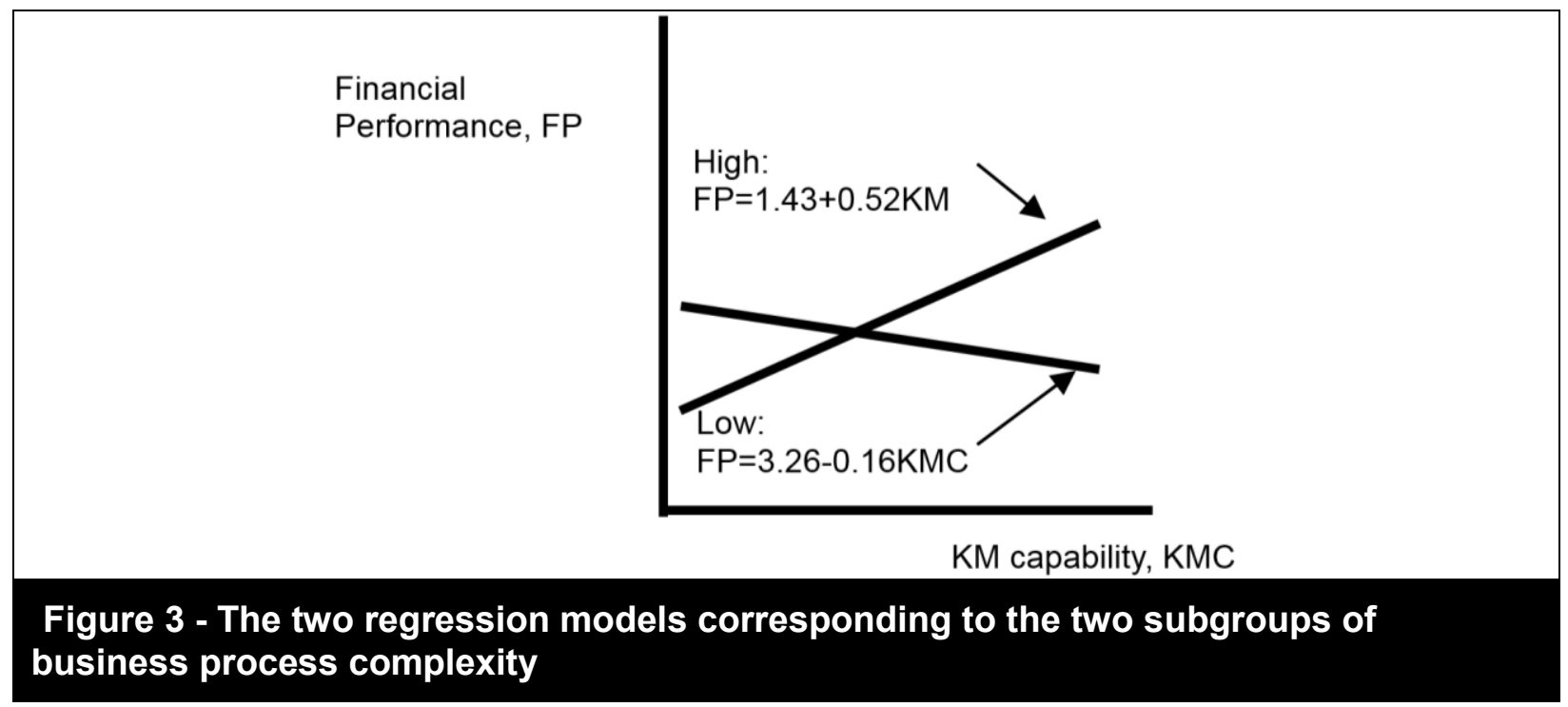

The observations above indicate that only three factors among the eight listed in hypotheses 2 have significant moderation effects on the KMC-financial performance relationship: business process complexity, leadership style, and the extent of IT readiness.

\section{Discussion}

This study demonstrates empirically that there are significant positive relationships between KM capabilities and organizational performance, measured both in terms of managerial performance and financial performance. It also shows that some of the eight contingency factors moderate this relationship. The form of moderation is initially hypothesized to be the same for all eight factors, but the nature of the moderating effects is demonstrated by the analysis to be different. The strength of the relationship between $\mathrm{KMC}$, and managerial and financial performance re-enforces the belief that there are significant benefits derived from KMC. Apparently, since no cost-benefit assessment was performed, these results cannot confirm that achieving KMC's benefits will always be worth the cost. 
However, the moderation analyses begin to address this question. For instance, in situations where production complexity is high, the benefits of KMC are particularly strong in both managerial and financial terms. Since knowledge is typically embedded in both the products and processes of manufacturers, it is useful to find that KMC benefits most those firms that have high levels of production complexity.

Interestingly, the openness of leadership has a particularly strong effect on the KMCfinancial performance relationship. Thus, $\mathrm{KMC}$ will provide more financial benefits to organizations that "invest" in an open style of leadership than to those that do not. IT support, which reflects management's allocation of adequate resources to technology and its motivation of participants to employ technology to the maximum degree that is feasible, also influences the KMC-financial performance relationship. Thus, organizations that "bet on" technology in these manners will find that KMCs are even more valuable.

The influence of business process complexity is somewhat more complex. Its greatest positive influence on the KMCfinancial performance relationship is primarily for firms at the higher levels of complexity. Two varieties of prescriptions may be made from these moderation results - those that relate to moderators that can be manipulated by management and those that relate to situational factors that are more difficult for management to influence. Organizations that have open leadership styles or sophisticated IT support should find KMC to be beneficial in financial terms. Conversely, firms that develop in open-leadership styles by investing in adequate IT resources and motivating employees to use IT should gain improved financial performance from KMC. In terms of situational factors, firms with high production complexity will find that KMC produce greater benefits in both managerial of financial terms. Firms at the very top levels of business process complexity should also find greater financial benefits from KMC.

These results have high face validity. In the area of $\mathrm{KM}$, the two most discussed enabling factors for KM are IT infrastructure (King, 2008) and a "knowledge sharing culture" (Davenport and Prusak, 1998). The two controllable moderators - IT support and leadership openness -- proved to be significant in this study, thus relating directly to these well-accepted enablers.

The two situational factors that proved to be most significant moderators are production complexity and very high levels of sales/marketing complexity. Perhaps, this result is due to the fact that more than twothirds of the sample firms were engaged in manufacturing. These two factors are prototypical of knowledge-intensive functions in manufacturing firms (as discussed in the first paragraph of this paper).

Another interesting finding is that the extended model and the moderated model reveal different insights into the KMCperformance relationships. Table 13 compares the relationships found in two models. Some factors found insignificant as enablers in the RBV-based model play significant roles in moderating the relationships between $\mathrm{KMC}$ and performance. For example, the complexity of business process has no effect on KMC in the extended model but moderates the relationship between KMC and performance, as shown in Figure 3 . This insight would have remained hidden if the moderated model were not adopted. Similarly, production complexity is found to enable $\mathrm{KMC}$ and moderate the effect of KMC on managerial performance. Leadership style that enables KMC also moderates the effect of $\mathrm{KMC}$ on financial performance; senior management support of IT has no effect on KMC but may suppress the effect of KMC on financial performance; IT readiness enable $\mathrm{KMC}$ and moderate the effect of $\mathrm{KMC}$ on financial performance. 


\begin{tabular}{|l|c|c|c|}
\hline \multirow{2}{*}{ Table 13 - Comparison of Results from Two Different Models } \\
\cline { 2 - 4 } Contingent Factors & Extended Model & \multicolumn{2}{c|}{ Contingency Model } \\
\hline Operational complexity (OC) & Factor-KMC & KMC-Managerial & KMC-Financial \\
\hline Competition (CT) & No & No & No \\
\hline Business Process complexity (BP) & No & No & Predictor \\
\hline Production complexity (PC) & No & Predictor & Homologizer \\
\hline Market dynamism (MD) & Enabler & Quasi Moderator & Predictor \\
\hline Leadership style (LS) & Enabler & Predictor & No \\
\hline IT support (ITS) & Enabler & No & Quasi Moderator \\
\hline IT readiness (ITR) & No & Predictor & Suppressor \\
\hline
\end{tabular}

\section{Conclusion}

Before elaborating on the research implications, it is important to acknowledge a few potential limitations of the study. One limitation comes from the scales used to measure the dependent construct. For practical reasons, we used 7-point Likertscales to collect data, which may have biases, though it is consistent with the recommendation in the social science literature.

The second limitation is related to the sample. The data collected for the research were from a single region and gathered through different channels, which may limit the external validity and generalizability of the findings. Since the main purpose of the research is not only to conclude on the effect of a specific factor but also to explore insights from different methods, this limitation does not restrict our contribution in this aspect. Nonetheless, this restriction triggers the issue of investigating the role of cultures in KM research. Leadership style is an organizational, cultural factor included in our study. There must be other national and organizational cultural factors that may moderate the effect of $\mathrm{KMC}$, and these factors provide a rich ground for potential further research.

Despite the limitations, this research reveals several interesting and important points about: (a) the analysis approach for forming and distinguishing the relationship moderator variable analysis, (b) the empirical evidence used to support the data analytic distinction, and (c) the merits of some analysis approaches of moderating effects proposed by Carte and Russell (2003), Frazier et al. (2004), and Sharma et al., 1981. Therefore, the contributions of the study are as follows:

1. The arguments of the types of moderator variable that rely on the use of different analysis approaches were shown to avoid error.

2. The recommendation that more subgroups be used in subgroup-type moderator analyses (i.e., homologizer) was demonstrated. The differences between quasi-moderator and pure moderator were defined clearly in this research.

3. The contingency approach offers an alternative view to RBV in examining the role of certain organizational factors in $\mathrm{KM}$ research and, more generally, in other IS research. As various studies explore different roles for the factors, greater insight concerning the impact of knowledge-management capabilities in various organizational contexts should be accumulated. This study adds to existing knowledge more in that multiple roles for each factor are investigated. We suggest that managers must realize these multiple roles in adopting KM.

4. Our research also contributes to research methods. Different findings from different models identify important issues in model selection, such as whether a factor should be treated as 
an enabler or a moderator. Unless there is strong theory to support a particular role, future researchers may wish to empirically and more comprehensively explore possible roles. In general, an enabler or predictor facilitates the realization of potential effects, whereas a moderator changes the direction of strength of the effects. They serve different management purposes, and some may be more useful than others. For example, the enabler view of production complexity indicates that a firm whose production process needs more knowledge on average has higher $\mathrm{KMC}$, but the moderating view indicates that higher KMC would result in higher managerial performance for firms with high production complexity. In this case, the latter finding may be more useful for managers in highly complex firms to adopt KM. Both findings, with respect to the leadership style that enables KMC and moderates the effect of KMC on financial performance, would be useful. Managers know that the firms with participative-leadership style would have higher KMC, which would positively affect financial performance.

5. We have provided a set of procedures extended from Sharma's basic framework for testing moderation effects. This mechanism takes into consideration both the regression coefficient of the interaction term and the power of the regression model to alleviate some common errors that have been found in previous IS research (Carte and Russell, 2003). We suggest that researchers follow this rigorous procedure to assess the existence of the moderating effect in future research.

This study has adopted a contingency approach to examine the relationship between knowledge management capabilities and firm performance, as well as the roles of eight contingency factors. We have arrived at conclusions using a moderation analysis that are consistent with the accepted wisdom of the KM field but which also identify more interesting relationships. Researchers should find the variety of analysis in this study useful for providing additional insights.

\section{References}

Alavi, M., and Leidner, D. E.(2001). "Review: Knowledge Management and Knowledge Management Systems: Conceptual Foundations and Research Issues," MIS Quarterly ,25(1), pp. 107-136.

Attharangsun, N. and Ussahawanitchakit, P.(2008). "The Antecedents and Consequences of CRM Effectiveness in Heath Service Industry of Thailand," Review of Business Research, 8(4), pp. 1-15.

Barney, J. (1991). "Firm Resources and Sustained Competitive Advantage," Journal of Management ,17(1), pp. 99120.

Becerra-Fernandez, I., and Sabherwal, R.(2001). "Organizational Knowledge Management: a Contingency Perspective," Journal of Management Information Systems ,18(1), pp. 23-55.

Bierly, P. E., and Chakrabarti, A. K. (1996). "Generic Knowledge Strategies in the U.S. Pharmaceutical Industry," Strategic Management Journal, (17), pp. 123-135.

Birkinshaw, J., Nobel, R., and Ridderstrale, J.(2002). "Knowledge as a Contingency Variable: Do the Characteristics of Knowledge Predict organization Structure?" Organization Science ,13(3), pp. 274-289.

Carte, T. A., and Russell, C. J. (2003). "In Pursuit of Moderation: Nine Common Errors and Their Solutions," MIS Quarterly ,27(3), pp. 479-501.

Choi, B., and Lee, H. (2003). "An Empirical Investigation of $\mathrm{KM}$ Styles and their 
Effect on Corporate Performance," Information and Management ,40(5), pp. 403-417.

Choi, S.Y., Lee, H., and Yoo, Y. (2010)."The Impact of Information Technology and Transactive Memory Systems on Knowledge Sharing, Application, and Team Performance: A Field Study," MIS Quarterly ,34(4), pp. 855-870.

Chuang, S. (2004). "A Resource-Based Perspective on Knowledge Management Capability and Competitive Advantage: an Empirical Investigation," Expert Systems with Applications, 27(3), pp. 459-465.

Cui, A. S., Griffith, D. A., and Cavusgil, S. T. (2005). "The Influence of Competitive Intensity and Market Dynamism on Knowledge Management Capabilities of Multinational Corporation Subsidiaries," Journal of International Marketing ,13(3), pp. 32-53.

Davenport, T. H. (1997). "Ten Principles of Knowledge Management and Four Case Studies," Knowledge and Process Management ,4(3), pp. 187208.

Davenport, T. H., and Prusak, L. (1998). Working Knowledge: How Organizations Manage What They Know, Harvard Business School Press, Boston.

Doty, D. H., Glick, W. H., and Huber, G. P.(1993). "Fit, Equifinallity, and Organizational Effectiveness: a Test of Two Configurational Theories," Academy of Management Journal ,36(6), pp. 1196-1250.

Durcikova, A., and Gray, P. H. (2009), "How Knowledge Validation Processes Affect Knowledge Contribution", Journal of Management Information Systems, 25(4), pp. 81-108

Dyer, J. H., and Nobeoka, K. (2000). "Creating and Managing a HighPerformance Knowledge-Sharing Network: the Toyota case," Strategic
Management Journal, (21), pp. 345367.

Eftekharzadeh, R.(2008). "Knowledge Management Implementation in Developing Countries: An Experimental Study," Review of Business, 28(3), pp. 44-58.

Eisenhardt, K., and Tabrizi, B. (1995). "Accelerating Adaptive Processes: Product Innovation in the Global Computer Industry," Administrative Science Quarterly,(40), pp. 84-110.

Fang, Y., Jiang, F., Makino, S., and Beamish, P.W. (2010)."Multinational Firm Knowledge, Use of Expatriates, and Foreign Subsidiary Performance," Journal of Management Studies ,47(1), pp 27-54.

Fedor, D. B., Ghosh, S., Caldwell, S. D., Maurer, T. J., and Singhal, V. R. (2003). "The Effects of Knowledge Management on Team Members' Rating of Project Success and Impact," Decision Sciences ,34(3), pp. 513-539.

Frazier, P. A., Tix, A. P., and Barron, K. E.(2004). "Testing Moderator and Mediator Effects in Counseling Psychology Research," Journal of Counseling Psychology, 51(1), pp. 115-134.

Gandhi, S. (2004). "Knowledge Management and Reference Services," The Journal of Academic Librarianship, (30), pp. 368-381.

Gatingnon, H., and Xuereb, J. M.(1997). "Strategic Orientation of the Firm and New Product Performance," Journal of Marketing Research, (34), pp. 77-90.

Gold, A. H., Malhotra, A., and Segars, A. H. (2001). "Knowledge Management: an Organizational Capabilities Perspective," Journal of Management Information Systems ,18(1), pp. 185214. 
Grewal, R., and Tansuhaj, P. (2001), "Building Organizational Capabilities for Managing Economic Crisis: The Role of Market Orientation and Strategic Flexibility," Journal of Marketing, (65), pp. 67-80.

Herder, P. M., Veeneman, W. W., Buitenhuis, M. D. J., and Schaller, A.(2003). "Follow the Rainbow: A Knowledge Management Framework for New Product Introduction," Journal of Knowledge Management, 7(3), pp. 105-115.

Hislop, D. (2002). "Mission Impossible? Communicating And Sharing Knowledge via Information Technology," Journal of Information Technology, (17), pp. 165-177.

Holsapple, C.W. and Joshi, K.D. (2000). "An Investigation of Factors that Influence the Management of Knowledge in Organizations," Journal of Strategic Information Systems, 9 (2-3): 235-261.

Holsapple, C. W. and Singh, M. (2001). "The Knowledge Chain Model: Activities for Competitiveness," Expert Systems with Applications ,(20), pp. 77-98

Hunt, J. G., Osborn, R. N., and Larson, L. L. (1975). "Upper Level Technical Dynamism and First Level Leadership within a Noncontingency and Contingency Framework," Academy of Management Journal, 18(3), pp. 476488.

Jackson, C. (1999), "Process to Product Creating Tools for Knowledge Management, " Proceedings of Second European Conference on Knowledge Management, Lisbon Portugal.

Jap, S. D. (1999). "Pie-Expansion Efforts: Collaboration Processes in BuyerSeller Relationships," Journal of Marketing Research, (36), pp. 461-75.

Jaworski, B. J., and Kohli, A. K. (1993), "Market Orientation: Antecedents and
Consequences," Journal of Marketing, (57), pp. 53-70.

Joshi, K.D., Chi, L., Datta, A., and Han, S. (2010),"Changing the Competitive Landscape: Continuous Innovation Through IT-Enabled Knowledge Capabilities," Information Systems Research (21), pp 472-495.

Juntarung, N., and Ussahawanitchakit, P.(2008). "Knowledge Management Capability, Market Itelligence, and Performance: an Empirical Investigation of Electronic Businesses in Thailand," International Journal of Business Research, 8(3), pp. 69-80.

Kankanhalli, A., Tan, B. C. Y., and Wei, K.K. (2005). "Contributing Knowledge to Electronic Knowledge Repositories: an Empirical Investigation," MIS quarterly, 29(1), pp. 113-143.

Kearns, G. S. (2006). The Effect of Top Management Support of SISP on Strategic IS management: Insights from the US Electric Power Industry," Omega, 34(3), pp. 236-253.

King, W. R.(2008). "An Integrated Architecture for an Effective Knowledge Organization," Journal of Knowledge Management, 12(2), pp. 29-41.

Kluge, J., Stein, W. \& Licht, T. (2001). Knowledge Unplugged : Bath Press,Bath.

Kulkarni, U., Ravindran, S., and Freeze, R. Winter (2006/2007). "A Knowledge Management Success Model: Theoretical Development and Empirical Validation," Journal of Management Information Systems, 23(3), pp. 309-347.

Kuo, Y.-K. and Ye, K.-D. (2010). "How employees' perception of information technology application and their knowledge management capacity influence organizational performance," Behaviour \& Information Technology, 29(3), pp.287-303. 
Lakshman, C., and Parente, R. C. (2008). "Supplier-Focused Knowledge Management in the Automobile Industry and Its Implications for Product Performance," Journal of management Studies, 45(2), pp. 317342.

Lee, S., Kim, B.G., Kim, H.(2012). "An integrated view of knowledge management for performance," Journal of Knowledge Management, 16(2) , pp.183-203.

Lee, C., Lee, K., and Pennings, J. M. (2001). "Internal Capabilities, External Networks, and Performance: A Study on Technology-based Ventures," Strategic Management Journal, (22), pp. 615-640.

Lee, H., and Choi, B. (2003). "Knowledge Management Enablers, Processes, and Organizational Performance: an Integrative View and Empirical Examination," Journal of Management Information Systems ,20(1), pp. 179228.

Lee, J.-N. and Choi, B. (2010). "Determinants of knowledge management assimilation: An empirical investigation,"IEEE Transaction on Engineering Management,57(3), p. 430 - 449.

Lee, L. T. S. and Sukoco, B. M. (2007). "The Effects of Entrepreneurial Orientation and Knowledge Management Capability on Organizational Effectiveness in Taiwan: The Moderating Role of Social Capital," International Journal of Management ,24(3), pp. 549-572.

Likert, R. (1967). The Human Organization: Its Management and Value, McGrawHill : New York.

Liu, P.-L., Chen, W.-C. and Tsai, C.-H. (2005). An empirical study on the correlation between the knowledge management method and new product development strategy on product performance in Taiwan's industries. Technovation, 25(6), pp. 637-644.

Liu, D., Ray, G., and Whinston, A.B.(2010). "The Interaction Between Knowledge Codification and Knowledge-Sharing Networks," Information Systems Research , (21), pp.892-906.

Liu, P.-L., and Tsai, C.-H. (2007). "Effect of Knowledge Management Systems on Operating Performance: An Empirical Study of Hi-Tech Companies using the Balanced Scorecard Approach," International Journal of Management ,24(4), pp. 734-743.

Liu, P.-L., Chen, W.-C., and Tsai, C.H.(2004). "An Empirical Study on the Correlation between Knowledge Management Capability and Competitiveness in Taiwan's Industries," Technovation ,24(12), pp. 971-977.

Marwick, A.D. (2001). Knowledge management technology. IBM Systems Journal, 40(4), 814-830.

McEvily, S. K., and Chakravarthy, B. (2002). "The Persistence of Knowledge-Based Advantage: an Empirical Test for Product Performance and Technological Knowledge," Strategic Management Journal ,23(4), pp. 285306.

Mills, A.M., Smith, T.A.(2011) . "Knowledge management and organizational performance: a decomposed view,"Journal of Knowledge Management, 15(1), pp.156-171.

Napaporn, J. and Phapruke, U. (2008). "Knowledge Management Capability, Market Intelligence, and Performance: An Empirical Investigation of Electronic Businesses inThailand," the IABE-2008 Annual Conference, Las Vegas, USA.

Nonaka, I., and Takeuchi, H. (1995), The knowledge creating company: how Japanese companies create the 
dynamics of innovation : Oxford University Press, New York.

Nunnally, J. C. (1967). Psychometric Theory:Mc Graw-Hill, New York.

Oh, W., and Pinsonneault, A.(2007). "On the Assessment of the Strategic Value of Information Technologies: Conceptual and Analytical Approaches," MIS Quarterly ,31(2), pp. 239-265.

Patnayakuni, R., Ruppel, C. P., and Rai, A. (2006). "Managing the Complementarily of Knowledge Integration and Process Formalization for Systems Development Performance," Journal of the Association for Information Systems ,7(8), pp. 545-567.

Pee, L. G., Kankanhalli, A., and Kim, H. W. (2010) . "Knowledge Sharing in Information Systems Development: A Social Interdependence Perspective," Journal of the Association for Information Systems,11(10), pp. 550575

Porter, M. (1985). Competitive Advantage: Creating and Sustaining Superior Performance.Free Press, New York.

Porter, M.E. (1979). "How Competitive Forces Shape Strategy, " Harvard Business Review.

Premkumar, G., and Roberts, M. (1999). "Adoption of New Information Technologies in Rural Small Businesses," Omega ,27(4), pp. 467484.

Ruggles, R. (1998). "The State of the Notion: Knowledge Management in Practice," California Management Review, 40(3), pp. 80-86.

Sharma, S., Durand, R. M., and Gur-Arie, O. (1981). "Identification and Analysis of Moderator Variables,"Journal of Marketing Research 18(3), pp. 291300.
Skyrme, D., and Amidon, D. (2000). The Knowledge Agenda. In Hermans, J. (ed.). The Knowledge Management Yearbook 1999-2000,ButterworthHeinemann, USA.

Slater, S. F., and Narver, J. C.(1995). "Market Orientation and the Learning Organization," Journal of Marketing, 59(3), pp. 63-74.

Spender, J.C. and Grant, R. (1996). "Knowledge and the Firm: Overview," Strategic Management Journal, (17), pp. 5-10.

Tanriverdi, H. (2005). "Information Technology Relatedness, Knowledge Management Capability, and Performance of Multibusiness Firms," MIS Quarterly, 29(2), pp. 311-334.

Tseng, S.-M. and Lee,P.-S. (2014) . "The effect of knowledge management capability and dynamic capability on organizational performance,"Journal of Enterprise Information Management, 27( 2), pp.158-179

Wang, E., Klein, G., and Jiang, J. J. (2007). "IT Support In Manufacturing For A Knowledge Management Dynamic Capability Link to Performance," International Journal of Production Research, 45(11), pp. 2419-2434.

Yang, J. (2005). "Knowledge integration and innovation: Securing new product advantage in high technology industry," Journal of High Technology Management Research, (16), pp. 121135.

\section{About the Author}

Yen-Ching OuYang is an Associate Professor of commerce automation \& management department in National Pingtung University, Taiwan. Her areas of interest include IT management, knowledge management and project management. 